\title{
The contribution of short-wave breaking to storm surges: The case Klaus in the Southern Bay of Biscay
}

\author{
Lavaud Laura ${ }^{1,{ }^{*}}$, Bertin Xavier ${ }^{1}$, Martins Kévin ${ }^{1}$, Arnaud Gael ${ }^{2}$, Bouin Marie-Noëlle ${ }^{3,4}$
}

1 UMR 7266 LIENSs, CNRS/La Rochelle Université, 2 rue Olympe de Gouges, 17000, La Rochelle,

France

2 Metocean Solutions Ltd, 5 Wainui Road, 3225 Raglan, New Zealand

3 UMR 3589 CNRM, Météo-France/CNRS, Université de Toulouse, Toulouse, France

4 UMR 6523 Laboratoire d'Océanographie Physique et Spatiale (LOPS), CNRS/lfremer/IRD/UBO, IUEM, Plouzané, France

*Corresponding author : Laura Lavaud, email address : laura.lavaud@univ-Ir.fr

\begin{abstract}
:
This study investigates the contribution of short-wave breaking to storm surges through a high-resolution hindcast of the sea state and storm surge associated with the extra-tropical storm Klaus. This storm made landfall in January 2009 in the Southern Bay of Biscay and produced the largest storm surges observed in this region over the last 20 years, with $1.70 \mathrm{~m}$ in the Arcachon Lagoon and $1.10 \mathrm{~m}$ in the Adour Estuary. A fully-coupled 3D modelling system, which uses a vortex force formalism to represent wave-current interactions, is applied with a spatial resolution down to $35 \mathrm{~m}$ in the surf zones in order to properly compute the wave-induced setup. Modelling results reveal that the wave setup contributes by up to $40 \%$ and $23 \%$ to the storm surge peak in the Adour Estuary and the Arcachon Lagoon respectively. Accounting for wave forces in the circulation model improves storm surge predictions by 50 to $60 \%$. This is explained by the dominant role played by wave forces in the momentum balance at the inlets under storm waves. Numerical experiments further reveal that the wave-induced setup can be tidally-modulated, although this phenomenon seems to be site-specific. Finally, a sensitivity analysis highlights the importance of the model grid resolution in the surf zones to correctly resolve the wave setup along open-ocean coasts. Inside the lagoon, the storm surge and wave setup are less sensitive to the grid resolution while tidal propagation cannot be accurately represented with a resolution of $1000 \mathrm{~m}$, which is typically used in operational storm surge forecast.
\end{abstract}

\section{Highlights}

- High-resolution hindcast of sea state and storm surge associated with storm Klaus. The wave setup substantially contributes to the storm surge in sheltered areas. The wave forces play a dominant role in the momentum balance at the inlet. The wave setup can be tidally-modulated while this process is site-specific. Wave setup calculation requires a high grid resolution of open-ocean coastal areas.

Keywords : Storm surge, Wave setup, SCHISM, Klaus 


\section{Introduction}

Coastal flooding can be one of the most destructive natural catastrophes. In recent years, the combined effects of demographic growth and economic development of coastal zones with the ongoing sea level rise increased coastal flooding risk (Muis et al., 2016). This risk can be locally aggravated by land subsidence in some regions worldwide such as the Ganges-Brahmaputra Delta in Bangladesh (Karpytchev et al., 2018; Krien et al., 2019) or along the Mississippi Delta in the Gulf of Mexico (Letetrel et al., 2015). To assess future population changes in low-lying coastal zones, Neumann et al. (2015) conducted a global analysis combining socio-economic and sea level rise scenarios. These authors suggested that the number of people living in low-lying coastal zones in 2000 ( 625 million) will increase by $50 \%$ by 2030 and will double by 2060 , which stresses the need to improve coastal communities resilience in the near future. On a more fundamental perspective, a better knowledge on the physical processes controlling storm-induced flooding is crucial to mitigate the consequences of these phenomena. Hurricane Katrina in the Gulf of Mexico (2005), storm Xynthia in the central part of the Bay of Biscay (2010), hurricane Sandy in the region of New York (2012) or typhoon Haiyan in the Philippines (2013) are major disasters which occurred over the past 20 years and illustrate this necessity.

Storm-induced coastal flooding results from extreme sea levels, which mostly occur when a high spring tide coincides with a large storm surge, although the importance of this combination depends on the ratio between the storm surge and the local tidal range. Storm surges correspond to variations of the ocean free-surface mainly caused by wind-induced surface stress and atmospheric pressure gradients associated with extra-tropical storms, tropical hurricanes and typhoons (Flather, 2001). Since the wind effect is inversely proportional to the water depth, low-lying coastal zones bordered by a large continental shelf, and located on storm tracks, are particularly vulnerable to storm surges and coastal flooding hazards.

While wind-induced surface stress and atmospheric pressure gradients have been identified as the main storm surge drivers since the early twentieth century (Doodson, 1924), the contribution of wind-generated surface waves 
(hereafter short waves) to storm surges has received much less attention and remains only partly understood. Charnock (1955) and Stewart (1974) revealed that a young sea state can result in a higher surface stress and thus a higher storm surge, which was corroborated by Donelan et al. (1993), Mastenbroek et al. (1993), Brown and Wolf (2009), Nicolle et al. (2009) and Bertin et al. (2015a) among others. Besides this effect, the breaking of short waves in coastal zones drives an increase in the mean water levels along the shoreline, referred to as wave setup. This phenomenon was first explained physically by the radiation stress formalism of Longuet-Higgins and Stewart $(1962,1964)$, which corresponds to the momentum flux associated with propagation of short waves. The dissipation of short-wave energy in the nearshore induces spatial gradients of radiation stresses, which act as a horizontal pressure force driving currents and a setup along the shoreline. The absence of consensus on the representation of wave-current interactions in $3 \mathrm{D}$ has long restricted the computation of wave setup to $2 \mathrm{DH}$ radiation stress formalism. Over the last 15 years, new theories have emerged to represent wave-current interactions in 3D (Mellor, 2003; McWilliams et al., 2004; Ardhuin et al., 2008). Also, a few studies have shown that the depthvarying circulation in surf zones can increase the maximum wave setup along the shoreline of sandy beaches (Apotsos et al., 2007; Guérin et al., 2018). However, the relevance of 3D fully-coupled models to compute storm surges at regional scale with a resolution sufficiently fine to represent surf zones has yet to be evaluated.

While wave setup on beaches is well documented and has been studied for several decades (e.g., see Holman and Sallenger Jr, 1985; Nielsen, 1988; King et al., 1990; Raubenheimer et al., 2001; Apotsos et al., 2007), its correct representation in storm surge numerical models requires a good description of the surf zones through refined meshes, which poses a serious challenge in terms of computational time for regional applications. However, thanks to the recent development of parallel computing techniques and the access to more computational resources, it is nowadays possible to represent the wave setup in storm surge modelling systems at regional scale (Dietrich et al., 2010; Bertin et al., 2015a; Krien et al., 2017) and better understand its impact. Several authors revealed that the wave-induced setup can substantially contribute to the storm surge under energetic wave conditions, and even dominate the other drivers along coasts characterised by narrow to moderately-wide shelves (Lerma et al., 2017) or at volcanic islands (Kim et al., 2010; Kennedy et al., 2012; Pedreros et al., 2018). The wave setup can range from several tens of centimetres to values of about $1 \mathrm{~m}$ near the shoreline (Pedreros et al., 2018; Guérin et al., 2018) while regional 
wave setup can reach tens of centimetres (Bertin et al., 2015a; Fortunato et al., 2017). However, the contribution of wave setup in harbours where tide gauges are usually located is not fully clear in the scientific community (e.g., Thompson and Hamon, 1980). Melet et al. (2018) suggested that the wave setup is negligible in most of the sheltered areas, while Aucan et al. (2012) reported that the Midway tide gauge, located in the interior lagoon of Midway Atoll in the Northern Hawaiian Islands, recorded high sea level anomaly (SLA) events corresponding to the wave setup driven by breaking waves during storms. The authors even suggested that the seasonal number of SLA events recorded at this tide gauge can be used as an index of the storminess in the Central North Pacific over climatic time-scales, as they found a good correlation between the two.

Recently, several studies combining numerical modelling with field observations suggested that the breaking of short waves over the ebb deltas of shallow inlets (Malhadas et al., 2009; Olabarrieta et al., 2011; Dodet et al., 2013; Wargula et al., 2018) or large estuaries (Bertin et al., 2015a; Fortunato et al., 2017) can induce a wave setup that extends at the scale of the whole lagoon or estuary. Thus, modelling the wave setup appears to be fundamental for the prediction of flood inundation levels and floodplain management of embayments, estuaries and river entrances (Hanslow and Nielsen, 1992).

This study presents a high-resolution hindcast of the sea state and storm surge induced by the violent extra-tropical storm Klaus, which made landfall in the Bay of Biscay on the $24^{\text {th }}$ of January 2009. As Klaus produced the most energetic waves ever recorded in the southern part of the bay, this storm represents a unique opportunity to investigate the contribution of short-wave breaking to storm surges. This process is examined in two sheltered areas of the French Aquitanian Coast where Klaus drove the largest storm surges observed over the last 20 years: the Arcachon Lagoon and the Adour Estuary. A fully-coupled $3 \mathrm{D}$ modelling system with the vortex force formalism of Bennis et al. (2011) is applied at the scale of the Bay of Biscay and the English Channel. The relevance of the 3D model in terms of storm surge and wave setup is compared against a conventional $2 \mathrm{DH}$ approach. Additional numerical experiments are conducted in order to analyse the impact of the wave forces on the momentum balance at the inlet of the Arcachon Lagoon and their tidal modulation at both studied locations. Lastly, a sensitivity analysis is carried out to analyse the impact of the grid resolution on storm surge and wave setup predictions. 


\section{The studied area and storm}

\subsection{Study area}

The Bay of Biscay is located in the North-East Atlantic Ocean, bordered by France to the east and Spain to the south. The study area is the Aquitaine coast in the south-eastern part of the Bay of Biscay, which comprises two major geomorphologic settings: a first unit from the northern Spanish coast to the Adour Estuary, characterised by rocky cliffs and small creeks, and bordered by a continental shelf only $20 \mathrm{~km}$-wide, and a second one from the Adour Estuary to the Gironde Estuary, with a sandy coast bordered by a continental shelf which width increases up to $150 \mathrm{~km}$ in front of the Gironde Estuary. This study focuses on two specific locations, the Arcachon Lagoon and the Adour Estuary further south (Fig. 1), which allows to investigate the influence of short-wave breaking in areas sheltered from this process.

The Arcachon Lagoon (Fig. 1-B) is a semi-enclosed bay, which extends at high-tide over an area of $160 \mathrm{~km}^{2}$. The head of the embayment is occupied by intertidal muddy and sandy flats that account for $75 \%$ of the lagoon, and divided by a large and complex network of secondary channels. The lagoon is connected to the ocean by a $5 \mathrm{~km}$-wide tidal inlet, bounded to the north by the $18 \mathrm{~km}$-long Cap Ferret sand-spit. The inlet is characterised by a welldeveloped ebb-tidal delta covering $12 \mathrm{~km}^{2}$, two deep channels, called North Pass and South Pass, and a poorly-developed flood-tidal delta of $2.3 \mathrm{~km}^{2}$ (Michel and Howa, 1997). The tidal regime is semi-diurnal and mesotidal, with a tidal range from $0.94 \mathrm{~m}$ to $4.93 \mathrm{~m}$ and a mean value of $2.94 \mathrm{~m}$ (Dodet et al., 2019). The channels are tide-dominated, with currents 20-30\% stronger in the North Pass than in the South Pass (Salles et al., 2015). Because of the well developed ebb delta and the sandbar (continuation of Cap-Ferret), the swells do not propagate inside the Arcachon Lagoon (Nahon, 2018) and the outer inlet can be often saturated with wave breaking (Senechal et al., 2013). According to the hydrodynamic classification proposed by Hayes (1980), the Arcachon Lagoon corresponds to a "transitional inlet" under a "mixed-energy regime".

The Adour Estuary (Fig. 1-C), located approximately $40 \mathrm{~km}$ north of the Spanish border, is defined by a narrower channel with a width varying between 150 (inlet mouth) and $500 \mathrm{~m}$ over the last $6 \mathrm{~km}$ of the river. Two breakwaters protect the entrance of the harbour of Bayonne from longshore currents and swell waves and help stabilizing the navigation channel. The influence of the breakwaters on the storm surge in the Adour Estuary will be discussed later in this study. The tidal regime of the area is semi-diurnal and mesotidal, with a tidal range varying from 0.78 to $4.32 \mathrm{~m}$ and a mean 
value of $2.53 \mathrm{~m}$ (Dodet et al., 2019). Tidal currents are weak in the outer part of the estuary with values lower than $0.20 \mathrm{~m} . \mathrm{s}^{-1}$ while in the river mouth, velocities reach values between 1 and $2 \mathrm{~m} . \mathrm{s}^{-1}$ during spring tides (Brière, 2005). The river flow discharge ranges from 30 to $2000 \mathrm{~m}^{3} \cdot \mathrm{s}^{-1}$ with an annual mean of about $300 \mathrm{~m}^{3} \cdot \mathrm{s}^{-1}$ (Bellafont et al., 2018).

Dodet et al. (2019) analysed wave regimes along the metropolitan coasts of France and provided yearly means of wave parameters along the $30 \mathrm{~m}$ isobath line. According to their study, yearly-averaged significant wave height in front of Arcachon and Bayonne is about $1.65 \mathrm{~m}$. Yearly averages of mean wave period and mean wave direction at Arcachon (respectively Bayonne) are about $6.3 \mathrm{~s}$ (resp. $7.15 \mathrm{~s}$ ) and about $290^{\circ}$ (resp. $310^{\circ}$ ). The wave climate is however characterised by important seasonal variations: at Arcachon (resp. Bayonne), the significant wave height has a winter average of $2.08 \mathrm{~m}$ (resp. $2.06 \mathrm{~m}$ ) and a summer average of $1.24 \mathrm{~m}$ (resp. $1.20 \mathrm{~m}$ ) and the mean period decreases by $2.5 \mathrm{~s}$ (resp. $1.5 \mathrm{~s}$ ) between winter and summer. Seaward of the Arcachon Lagoon, storm waves can exceed $9 \mathrm{~m}$ in water depths of $26 \mathrm{~m}$ (Butel et al., 2002).

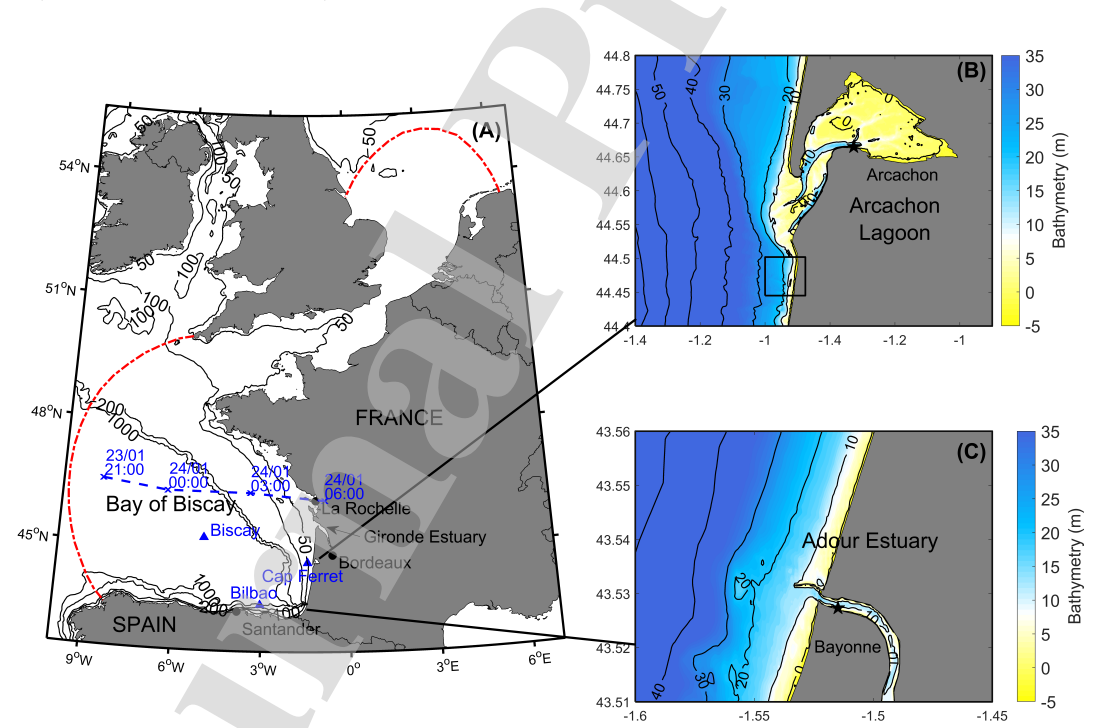

Figure 1: (A) Bathymetric map and extension of the computational domain (red dashdotted line), the storm track (blue dashed line and crosses) and the wave buoys (blue triangles) used in this study. (B) and (C) Detailed bathymetry of the studied areas with location of the tide gauges (black stars). The black box in (B) corresponds to the adjacent beach where the sensitivity of storm surge and wave setup predictions to the grid resolution is analysed. 


\subsection{The storm Klaus}

The extra-tropical storm Klaus hit the French coasts in the night of the $23^{\text {rd }}$ to the $24^{\text {th }}$ of January 2009. It induced the largest storm surge observed over the last 20 years in this region of the Bay of Biscay, with $1.10 \mathrm{~m}$ at Bayonne Boucau station and $1.70 \mathrm{~m}$ at Arcachon Eyrac station (Mugica et al., 2010; Arnaud and Bertin, 2014). Previous long-term records of wind speeds were exceeded in some French stations like Bordeaux and Bayonne with wind gusts of $44-50 \mathrm{~m} \cdot \mathrm{s}^{-1}$ and $33-39 \mathrm{~m} \cdot \mathrm{s}^{-1}$ respectively. It was considered as the most damaging wind storm to affect Northern Iberia and Southern France since the destructive storm Martin in late December 1999 (Liberato et al., 2011). In 2009, Klaus was the most costly weather events worldwide with over US $\$ 6.0$ billion in losses reported, mainly in France and Spain (Aon-Benfield, 2010). Liberato et al. (2011) described the storm from its genesis to its impact on the French and Spanish coasts and the main features of its evolution are summarized here. Klaus was first detected on 21 January 2009 as a small atmospheric wave perturbation. Due to the southward displacement of the polar jet stream, the winter cyclone moved eastward at an unusually low latitude (between $35^{\circ} \mathrm{N}$ and $45^{\circ} \mathrm{N}$ ), on the southern edge of the typical North-Atlantic storm track climatological envelope. It underwent an explosive development on 23 January around $21^{\circ} \mathrm{W}$, with a deepening rate of $37 \mathrm{hPa}$ in 24 hours, probably supported by an important tropical moisture export.

The storm rapidly reached the Bay of Biscay and followed a WNW to ESE track toward the coasts (Fig. 1-A). The Spanish Oceanographic Institute (IEO) registered two individual wave heights over $24 \mathrm{~m}$ from a buoy $35 \mathrm{~km}$ north of Santander between 06:00 and 07:00 in the morning of January $24^{\text {th }}$. Bilbao and Cap-Ferret buoys recorded significant wave heights reaching $13 \mathrm{~m}$ with a peak period of $15 \mathrm{~s}$ during the storm. The centre of the low-pressure system passed at 5:00 am on January $24^{\text {th }}$ over La Rochelle with a minimum of $965.8 \mathrm{hPa}$ recorded at the nearby station of Chassiron (Fig. 1-A). The highest sustained wind speeds were measured further south, with a maximum of $36 \mathrm{~m} . \mathrm{s}^{-1}$ at Cap-Ferret station (Arcachon Lagoon) for a lowest pressure of $976 \mathrm{hPa}$. At Bayonne, sustained wind speed reached $21 \mathrm{~m} . \mathrm{s}^{-1}$ with a minimum pressure of $983.6 \mathrm{hPa}$. 


\section{Methods and data}

\subsection{The modelling system}

\subsubsection{Overview of the modelling system}

This study uses the modelling system SCHISM (Semi-implicit Crossscale Hydroscience Integrated System Model) of Zhang et al. (2016) which is a 3D unstructured-grid model. The model uses a combination of a semiimplicit scheme and an Eulerian-Lagrangian Method to treat the momentum advection, which allows to relax the associated numerical stability constraints. Compared to the original model SELFE from which it is derived (Zhang and Baptista, 2008), SCHISM now integrates many enhancements and upgrades including new extension to large-scale eddying regime and a seamless cross-scale capability from creek to ocean (Zhang et al., 2016; Ye et al., 2020). A detailed description of SCHISM, the governing equations and its numerical implementation can be found in Zhang et al. $(2015,2016)$. The hydrostatic solver of SCHISM can be coupled with other modules incorporated in the modelling system such as short waves, sediment transport, water quality, oil spills and biology. The generation and propagation of short waves are simulated with the Wind Wave Model WWMII of Roland et al. (2012). In this study, the contribution of short-wave breaking to storm surges is analysed from 3D fully-coupled (wave-current) simulations. The hydrodynamic and spectral wave models share the same unstructured grid and domain decomposition, which reduces the exchange of information between the models and eliminates errors associated with interpolation.

\subsubsection{Vortex force formalism}

In the modelling system, the 3D wave-current interactions are represented with the vortex force formalism proposed by Ardhuin et al. (2008), as described in Bennis et al. (2011). Its detailed implementation in SCHISM can be found in Guérin et al. (2018). In the vortex force framework, the mass conservation and momentum equations of the hydrodynamic model read:

$$
\nabla \cdot \hat{\mathbf{u}}=0
$$

$$
\frac{D \hat{u}}{D t}=f \hat{v}-\frac{1}{\rho} \frac{\partial P_{A}}{\partial x}-g \frac{\partial \zeta}{\partial x}+\frac{\partial}{\partial z}\left(\nu \frac{\partial \hat{u}}{\partial z}\right)+F_{\text {wave }, x}
$$

$$
\frac{D \hat{v}}{D t}=-f \hat{u}-\frac{1}{\rho} \frac{\partial P_{A}}{\partial y}-g \frac{\partial \zeta}{\partial y}+\frac{\partial}{\partial z}\left(\nu \frac{\partial \hat{v}}{\partial z}\right)+F_{\text {wave }, y}
$$

In Eq. (1), $\nabla=\left(\frac{\partial}{\partial x}, \frac{\partial}{\partial y}, \frac{\partial}{\partial z}\right)$ and $\hat{\mathbf{u}}=(\hat{u}, \hat{v}, \hat{w})$ is the quasi-Eulerian velocity, equal to the mean Lagrangian velocity $\mathbf{u}=(u, v, w)$ minus the Stokes 
velocity $\mathbf{u}_{\mathbf{s}}=\left(u_{s}, v_{s}, w_{s}\right)$. In Eqs. (2) and (3), $f$ is the Coriolis parameter, $\rho$ is the water density, $P_{A}$ is the sea-level atmospheric pressure, $g$ is the acceleration caused by gravity, $\zeta$ is the free surface elevation and $\nu$ is the vertical eddy viscosity. $F_{\text {wave }, x}$ and $F_{\text {wave } y}$ are the two components of the wave forces, given by:

$$
F_{\text {wave }, x}=v_{s}\left[f+\left(\frac{\partial \hat{v}}{\partial x}-\frac{\partial \hat{u}}{\partial y}\right)\right]-w_{s} \frac{\partial \hat{u}}{\partial z}-\frac{\partial J}{\partial x}+\hat{F}_{d, x}
$$

$$
F_{\text {wave }, y}=-u_{s}\left[f+\left(\frac{\partial \hat{v}}{\partial x}-\frac{\partial \hat{u}}{\partial y}\right)\right]-w_{s} \frac{\partial \hat{v}}{\partial z}-\frac{\partial J}{\partial y}+\hat{F}_{d, y}
$$

where $J$ is the wave-induced mean pressure, and $\hat{\boldsymbol{F}}_{d}$ is the wave-induced non conservative forces due to depth-induced wave breaking. A detailed description of the wave-induced non conservative forces can be found in Guérin et al. (2018).

\subsubsection{Model parametrisations for $2 D H$ and $3 D$ models}

There are noticeable differences between 2DH and 3D configurations. In 2DH, the model uses a Manning coefficient and the depth-integrated current velocity to evaluate the bottom stress, while in 3D, the model uses the bottom roughness and the velocity computed at the top of the bottom cell. In the 3D model, several parametrisations are available to compute the wave-enhanced bottom stress but a sensistivity analysis did not result in significant improvements, which corroborates the findings of Bertin et al. (2015a) in the central part of the Bay of Biscay. Therefore, wave effects on the bottom stress are not considered in the study. In the 3D model, the wave effects on vertical mixing are integrated in the turbulence closure scheme (Umlauf and Burchard, 2003) following the approach of Moghimi et al. (2013), as described in Guérin et al. (2018). For both 2DH and 3D models, the surface stress can be computed with a bulk formula of the form $\rho_{a} C_{d} U_{10}^{2}$, where $U_{10}$ is the $10 \mathrm{~m}$ wind speed and $C_{d}$ is the drag coefficient calculated with the formulation of Hwang et al. (2019). The surface stress can also be computed using a wave-dependent parametrisation using the friction velocity $U_{*}$ calculated in WWMII. Donelan et al. (1993) reported that a young sea state enhances the sea surface roughness. In order to correctly represent this process and predict the subsequent storm surge, Mastenbroek et al. (1993) and Bertin et al. (2015a) showed that a wavedependent surface stress is required. The influence of the surface stress formulation will be discussed later in this study. 


\subsubsection{The spectral wave model}

WWMII solves the equation for the conservation of the wave action (e.g., see Komen et al., 1994) to simulate the generation and propagation of wind-generated waves. The model accounts for wind input and energy dissipation by whitecapping, computed according to Ardhuin et al. (2010), energy dissipation due to bottom friction, which is modelled based on the results obtained during the JONSWAP project (Hasselmann et al., 1973), and depth-induced breaking computed according to the model of Battjes and Janssen (1978), which is parametrized with the breaker index $\gamma$ and the dissipation coefficient $B$. As wave measurements in the surf zone during the storm were not available, $\gamma$ and $B$ are set to the default values of 0.73 and 1 respectively, which will be discussed later. Finally, the non-linear wave-wave interactions are calculated following the Discrete Interaction Approximation of Hasselmann et al. (1985) and the Lumped Triad Approximation of Eldeberky (1996) in deep water and shallow water respectively. A detailed description of the coupling between SCHISM and WWMII can be found in Roland et al. (2012) and Schloen et al. (2017). At the coupling time step, SCHISM provides WWMII with fields of $2 \mathrm{DH}$ currents and water levels while SCHISM receives wave forces from WWMII.

\subsubsection{Model implementation}

The unstructured computational grid used to perform the hindcast of the storm covers the whole Bay of Biscay from $10^{\circ} \mathrm{W}$ to the French coasts, the English Channel and a part of the North Sea (up to $55^{\circ} \mathrm{N}$ ) (Fig. 1-A). The grid has $\sim 281000$ nodes in the horizontal, with a spatial resolution ranging from $5000 \mathrm{~m}$ along the open boundary to $35 \mathrm{~m}$ along the shoreline of the studied areas (i.e. the Arcachon Lagoon and the Adour Estuary). In the vertical, the grid is discretized in $35 \mathrm{~S}$ levels for the 3D simulations.

The circulation model is forced at its open boundaries by the 16 main astronomical constituents linearly interpolated from the regional model of Bertin et al. (2012). The tidal potential is switched off since a sensitivity analysis revealed a negligible effect on tidal predictions. After calibration of the tidal model, the bed roughness in the 3D model is set to $0.0001 \mathrm{~m}$ in the open ocean and $0.002 \mathrm{~m}$ in the Arcachon Lagoon and the Adour Estuary. In the 2DH model, a Manning coefficient of 0.02 is employed for the open ocean while a value of 0.029 is considered for the Adour Estuary and the Arcachon Lagoon. The Manning coefficient used for the Arcachon Lagoon is between the values used by Cayocca (1996) ( 0.028) and Nahon (2018) (0.032). The simulations are started on the $22^{\text {th }}$ of January 2009 , two days before the peak of the storm and last 4 days. The time step is set to $60 \mathrm{~s}$ for both 
the hydrodynamic and the wave models, in the 2DH and 3D simulations.

Over the whole domain, the circulation model is forced by hourly $10 \mathrm{~m}$ wind speed and sea-level pressure fields from the Climate Forecast System Reanalysis CFSR (Saha et al., 2010). The datasets are provided on a regular grid with a spatial resolution of $0.312^{\circ}$ and $0.5^{\circ}$ for the wind and the atmospheric pressure respectively. WWMII is forced with the CFSR wind fields over the whole domain. WWMII is also forced along the open boundaries by time series of directional wave spectra, previously computed from a regional application of the WaveWatchIII (WWIII) spectral wave model described in Bertin et al. (2015a). Wind fields from CFSR are also used to run the WWIII model over the North Atlantic Ocean.

\subsection{Wave and water level observations}

The accuracy of the wave predictions is evaluated with the measurements recorded by three buoys in the Bay of Biscay (see Fig. 1-A, for their location). The Biscay buoy is a non-directional buoy located by $4500 \mathrm{~m}$ depth, operated by Mto-France and UK Met Office. The Cap Ferret and Bilbao buoys are located in more intermediate water depths of the southern part of the Bay of Biscay (depths of $50 \mathrm{~m}$ and $600 \mathrm{~m}$ respectively) and are operated by CEREMA and Puerto del Estado respectively. The three buoys provide time series of significant wave height $\left(H_{s}\right)$ while the mean wave period $\left(T_{m 02}\right)$ is available at Cap Ferret and Biscay buoys and the peak wave period $\left(T_{p}\right)$ at Bilbao buoy. Wave bulk parameters are estimated every 60 minutes at Biscay and Bilbao buoys and every 30 minutes at Cap Ferret buoy. Since the atmospheric data used to force the model has a hourly time resolution, the wave predictions cannot represent the sub-hourly variability and the measurements at Cap Ferret buoy are therefore averaged over one hour to yield a consistent comparison with the model predictions.

Simulated water levels are validated through a comparison against observations recorded with a 10-min sampling interval during the storm period at the two tide gauges of Arcachon Eyrac and Bayonne Boucau (see Fig. 1-B and 1-C, for their respective location). A tidal prediction is obtained based on a 5 year-long time series (2008-2012) with a harmonic analysis using the UTide code (Codiga, 2011). Tides are reconstructed with the 67 main astronomical constituents previously computed. Note that in the North-East Atlantic Ocean, the constituent Sa results from a combination of thermo-steric and atmospheric effects (Bertin et al., 2015b; Payo-Payo and Bertin, 2020). Therefore, it is not included in the tidal prediction since storm surges are computed as the difference between the observed water level and the astronomic tidal prediction. 


\section{Modelling results}

\subsection{Atmospheric forcing}

In order to validate the atmospheric forcing originating from CFSR, a comparison is performed against field observations available during the storm and collected at the meteorological stations of Cap Ferret and Bayonne (see Fig. 1-A, for their location). The comparison (Fig. 2) of modelled against observed $10 \mathrm{~m}$ wind speeds (hereafter $\mathrm{U}_{10}$ ) and sea-level pressure (hereafter SLP) reveals that SLP is well reproduced with a root mean square error (hereafter RMSE) lower than $1.5 \mathrm{hPa}$ at both locations. At Cap Ferret, $\mathrm{U}_{10}$ is accurately predicted with a RMSE of $2.3 \mathrm{~m} . \mathrm{s}^{-1}$, although with a slight underestimation of approximately $4 \mathrm{~m} \cdot \mathrm{s}^{-1}$ two hours before the peak of the storm. Since the meteorological station at Bayonne is located at $75 \mathrm{~m}$ above sea level and $3 \mathrm{~km}$ inland, the model, providing $10 \mathrm{~m}$ wind speed with a $0.3^{\circ}$ resolution, does not accurately reproduce the observations, which probably explains the positive bias of $1.6 \mathrm{~m} \cdot \mathrm{s}^{-1}$. Overall, it should be noted that the intensity of the storm is correctly represented: peak values of $\mathrm{U}_{10}$ are reasonably predicted with stronger values at Cap Ferret $\left(34 \mathrm{~m} . \mathrm{s}^{-1}\right)$ than at Bayonne $\left(22 \mathrm{~m} \cdot \mathrm{s}^{-1}\right)$.
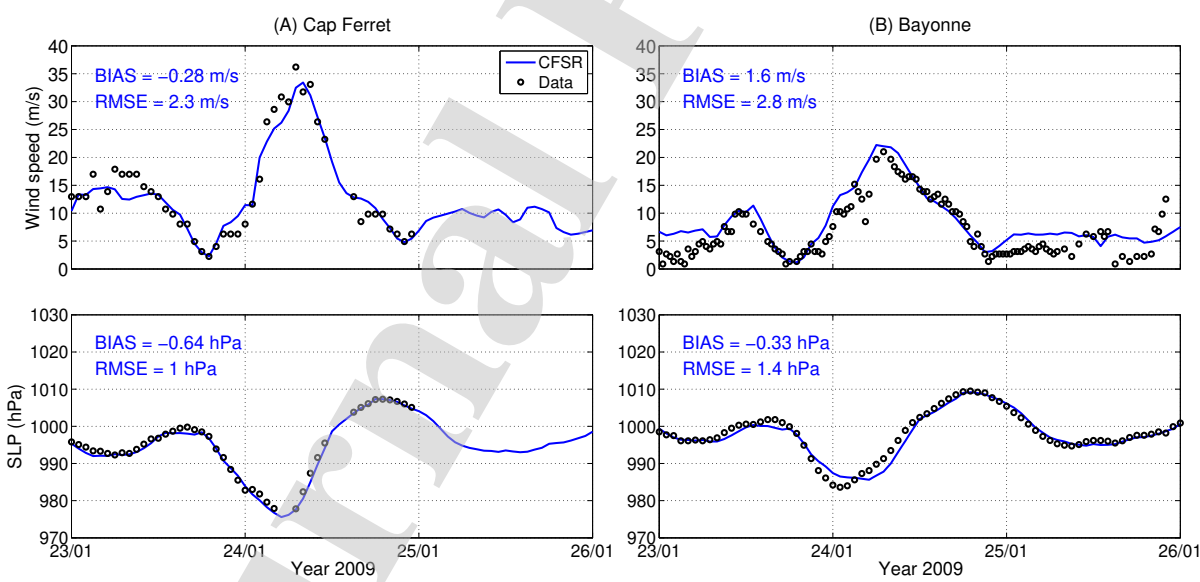

Figure 2: Modelled (blue solid line) against observed wind speeds and sea level pressure (black dots) at Cap Ferret (A) and Bayonne (B) stations.

\subsection{Wave predictions}

Modelled wave bulk parameters are compared against the measurements available during Klaus at Cap Ferret, Bilbao and Biscay buoys (Fig. 3). The comparison reveals a good agreement between modelled and measured data: 

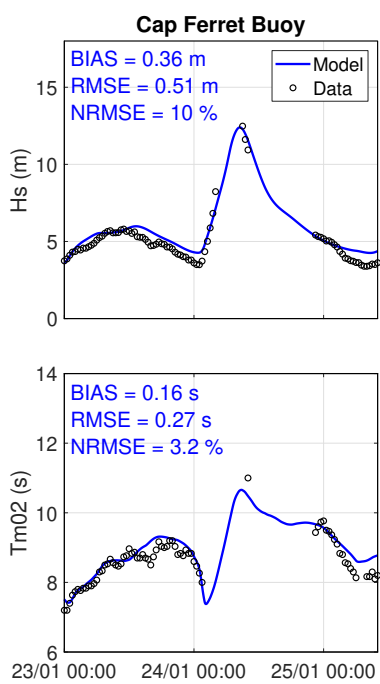
$\%$ NRMSE.
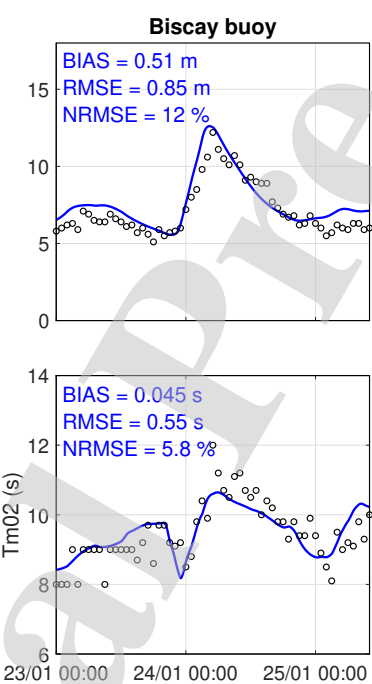
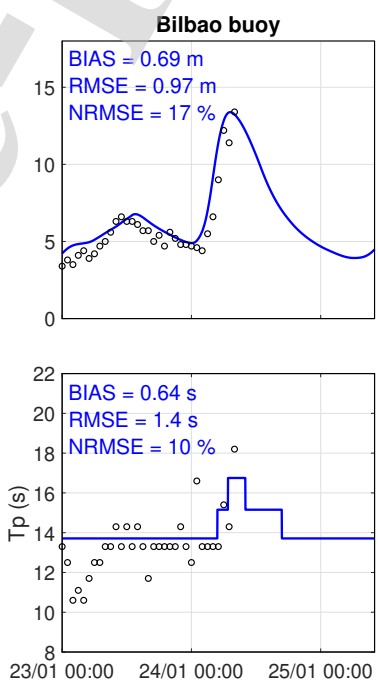

Figure 3: Observed (black dots) against modelled wave parameters (blue solid line) at Cap Ferret, Biscay and Bilbao buoys during Klaus.

$H_{s}$ is well reproduced with a RMSE ranging from 0.51 to $1 \mathrm{~m}$ which corresponds to a 10-17\% error once normalized by the mean of the observations (hereafter NRMSE). However, for the three stations, the model displays a positive bias of $0.35-0.50 \mathrm{~m}$ at Cap Ferret and Biscay buoys and $0.70 \mathrm{~m}$ at Bilbao buoy. It should be noted that the larger error at Bilbao buoy is partly due to a one-hour time lag, representing $35 \%$ of the bias and the NRMSE, which we are unable to explain. The model correctly captures the peak storm wave height with less than $10 \%$ error at the three buoys. $T_{m 02}$, available at Cap Ferret and Biscay buoys, is well predicted with a NRMSE less than $6 \%$ while at Bilbao buoy, $T_{p}$ is adequately reproduced with a 10

\subsection{Storm surge and water level predictions}

A tide-only simulation is first performed and the modelled water levels are compared against the tidal predictions based on the observations at each station. The tidal forcing together with the distribution of the Manning coefficient yields good results with a RMSE on tides of $0.11 \mathrm{~m}$ at Bayonne and $0.08 \mathrm{~m}$ at Arcachon (not shown).

The effect of the parametrisation of the surface stress on the storm surge is investigated by comparing simulations using the bulk formula of Hwang et al. (2019) and the wave-dependent approach (see Section 3.1.3). 
This comparison reveals moderate differences between both parametrisations (lower than $0.05 \mathrm{~m}$ ), with the predictions of the model using the bulk formula slightly better matching the observations. To explain the negligible effects of the wave-dependent approach on the storm surge predictions, the sea state is characterised by the wave age, defined as $C_{p} / U_{10}$ where $C_{p}$ is the peak wave phase speed. Considering a 20-hour window centred on the storm peak, the wave age varies from 0.7 to 2.3 , with an average value of 1.32 (with a standard deviation of 0.5 ), which is characteristic of a mature sea state and explains the very slight impact of the wave-dependent approach on the results. This behaviour corroborates the study of Bertin et al. (2015a), who showed that the surface stress was little dependent on the sea state for the storm Joachim, characterised by comparable wave height and peak period as during Klaus. According to these results, the bulk formula of the surface stress is adopted in the rest of the study.

The contribution of short-wave breaking to the storm surge is analysed by comparing a first simulation without wave forces and a fully-coupled simulation, i.e. including wave forces, hereafter referred to as the baseline model. The modelled storm surges are obtained by subtracting the tide-only simulation to each case of simulation.
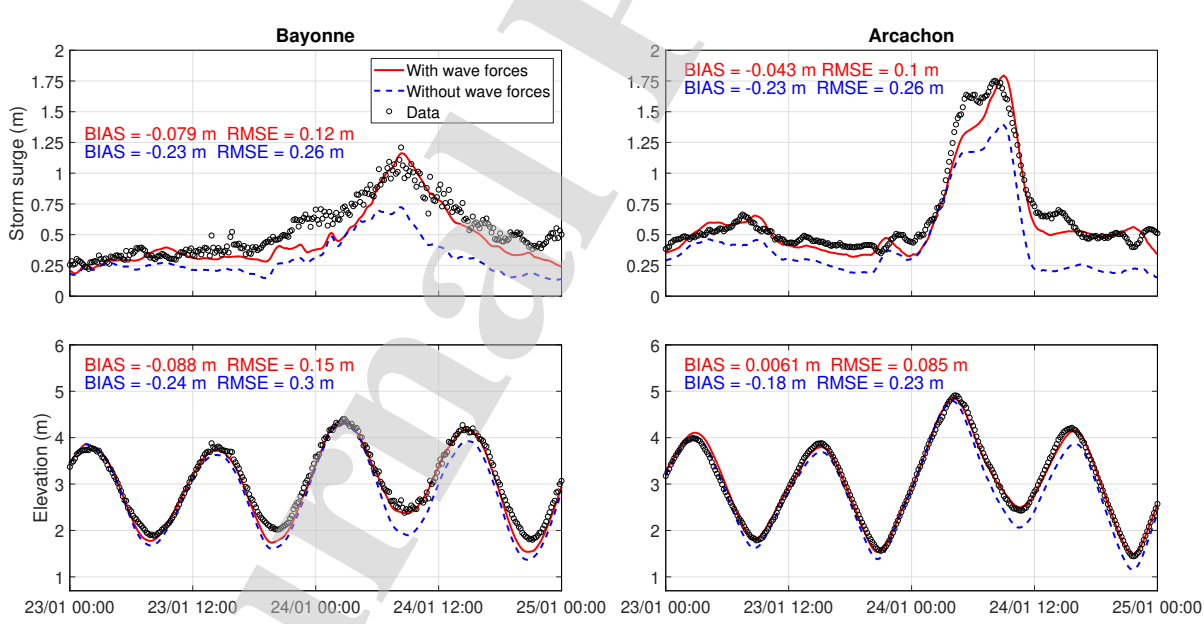

Figure 4: Observed (black dots) against modelled storm surges with the baseline model (red solid line) and the model without wave forces (blue dashed line) at Bayonne (left) and Arcachon (right).

The results are presented in Figure 4, where each simulation is compared against storm surges and water levels observed at Bayonne and Arcachon during the storm. The baseline model accurately reproduces the water levels 
with a RMSE of 0.09 and $0.15 \mathrm{~m}$ at Arcachon and Bayonne respectively. The storm surges are well predicted by the model, with a RMSE of $0.12 \mathrm{~m}$ at Bayonne and $0.10 \mathrm{~m}$ at Arcachon, although a $0.25 \mathrm{~m}$ underestimation is noticed at this station approximately two hours before the storm peak. Without wave forces, storm surge and water level predictions considerably deteriorate compared to the baseline model with a RMSE two to three times larger at both locations. The modelled water levels display a negative bias ranging from 0.18 to $0.24 \mathrm{~m}$. The surge peak is underestimated by $0.40-$ $0.45 \mathrm{~m}$ at Arcachon and Bayonne, which results in a negative bias of $0.23 \mathrm{~m}$ over the duration of the storm.

The comparison of both simulations reveals that the wave setup driven by the wave forces in the baseline model accounts for $40 \%$ and $23 \%$ of the surge peak in the Adour Estuary and the Arcachon Lagoon respectively, which explains that the baseline model much better matches the observed peak values.

In order to get a spatial overview of this process, modelled storm surges with and without wave forces, as well as their difference, are computed at the scale of the Arcachon Lagoon and the Adour Estuary (Fig. 5). In the Adour Estuary, the storm surge in the fully-coupled simulation increases by more than $0.5 \mathrm{~m}$ at adjacent beaches while beeing almost constant inside the estuary (Fig. 5-a). The comparison between Figure 5-c (atmospheric surge only) and Figure 5-e (wave setup only) reveals that this behaviour is due to the development of a wave setup along adjacent shorelines, reaching up to $0.75 \mathrm{~m}$ and extending at the scale of the whole estuary where it raises the water level by $0.45 \mathrm{~m}$. A different pattern can be observed in the Arcachon Lagoon, where the storm surge in the fully-coupled simulation increases from the inlet to the lagoon head (Fig. 5-b). The comparison between Figure 5$\mathrm{d}$ and Figure 5-f suggests that this behaviour results from the increase in atmospheric surge towards the lagoon head combined with the development of a wave setup reaching $0.40 \mathrm{~m}$ at the scale of the lagoon. As in the Adour Estuary, the wave setup develops at the inlet and then exhibits a plateau inside the lagoon. Along the adjacent shorelines of the lagoon, the maximum wave setup reaches $0.80 \mathrm{~m}$ (The maximum wave setup along the adjacent shorelines are not shown in Figures 5-e and 5-f as computational nodes dry in the tide-only simulation are not represented). 

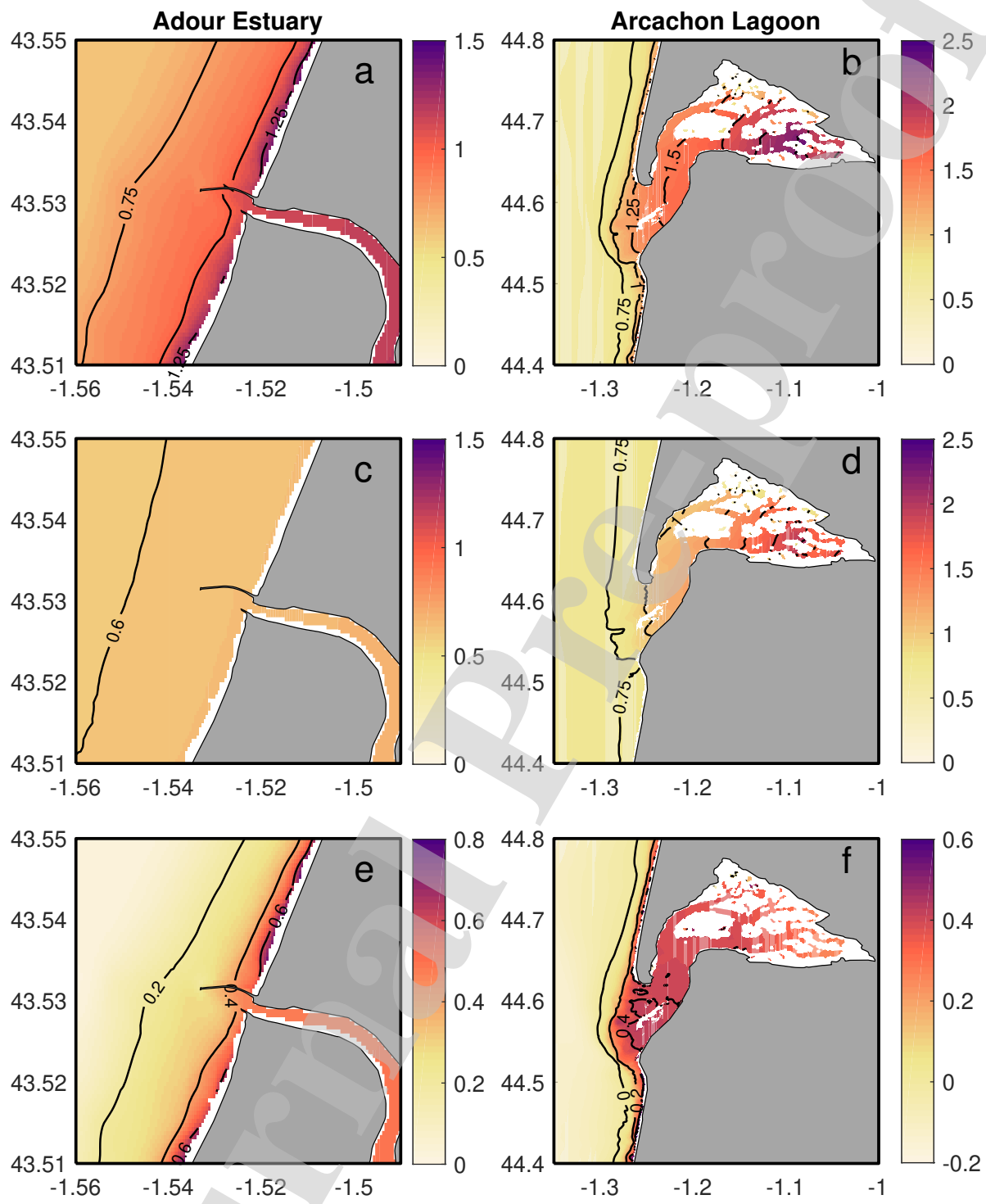

Figure 5: Storm surge (in $\mathrm{m}$ ) simulated with wave forces $(\mathrm{a}, \mathrm{b})$, without wave forces $(\mathrm{c}, \mathrm{d})$ and their difference (e,f), at the Adour Estuary (left) and the Arcachon Lagoon (right). The white color corresponds to dry nodes in the tide-only simulation. 


\section{Contribution of wave breaking to storm surges}

\subsection{Model predictive skills}

Wave parameters are accurately reproduced by the model and correspond to the state-of-the-art considering previously published studies led under storm wave conditions (e.g. Kerr et al., 2013; Bertin et al., 2012; Staneva et al., 2016). Storm surges are also well predicted, with errors similar or even lower compared to previously published studies (e.g. Kerr et al., 2013; Brown et al., 2013; Bertin et al., 2015a). In details, the storm surge is underestimated by up to $0.25 \mathrm{~m}$ during the first part of the storm peak at Arcachon. This can be explained by an underestimation of the CFSR sustained wind speeds by up to $4 \mathrm{~m} \cdot \mathrm{s}^{-1}$ during this period (Fig. 2), which leads to a wind-induced surge lower than expected. This hypothesis was tested by correcting wind speeds empirically on the time steps corresponding to this period (cf. Appendix A). The results reveal that this correction almost cancels out the local underestimation in the surge, thus supporting this hypothesis. In the Adour Estuary, model results at an earlier stage of this study showed a 0.05 to $0.1 \mathrm{~m}$ negative bias in the storm surge before the storm peak when the breakwaters bounding the estuary mouth were considered as impermeable wall. In fact, these breakwaters are made of large blocks (4 to 40 tons) that allow large amounts of water to flow through the structures when a gradient in water levels exists on both sides of the structure (Prof. Abadie, pers. com.). Such flows can take place when a wave setup develops at adjacent beaches, a process already reported at other engineered estuaries (Hanslow and Nielsen, 1992; Hanslow et al., 1996). In order to account for these possible flows, we took advantage of hydraulic structure options implemented in the code. Although this parametrisation improves storm surge prediction by $0.04 \mathrm{~m}$, verifying the adequate representation of these flows is outside the scope of the study and would deserve a specific analysis. 

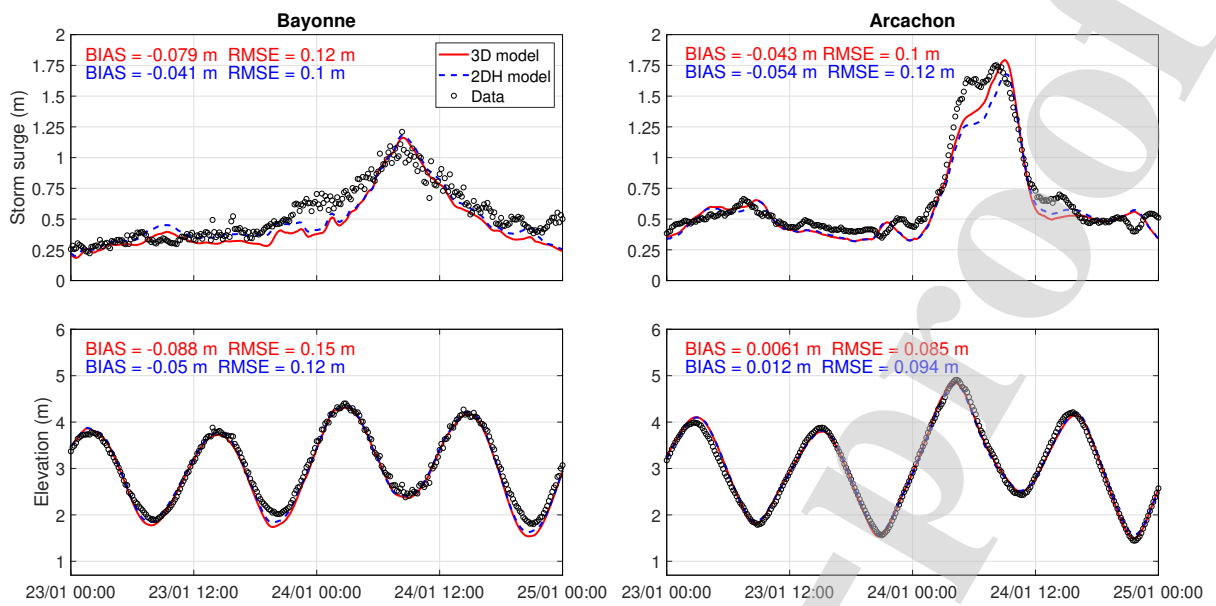

Figure 6: Observed (black dots) against modelled storm surges with the 3D baseline model (red solid line) and the 2DH model (blue dashed line) at Bayonne (left) and Arcachon (right).

The comparison of the results between the baseline model and the model without wave forces (Fig. 4) reveals that including wave forces in the circulation model substantially improves its predictive skills. The analysis of the different terms included in wave forces (Eq. 4 and 5) shows that the wave dissipation term by depth-induced breaking is clearly dominant over the vortex force and the wave mean pressure terms. In accordance with previous studies (Staneva et al., 2016), this analysis highlights the importance of accounting for short waves in storm surge modelling systems, provided that wave energy dissipation due to wave breaking is correctly represented. Guérin et al. (2018) investigated wave-induced circulation in a surf zone with varying bed slope. The authors computed the wave breaking process according to the model of Thornton and Guza (1983) in which they calculated the breaking index $\gamma$ and the dissipation coefficient $B$ as a linear function of the beach slope. The authors showed that this adaptive approach improved the predictions of short-waves bulk parameters and wave setup by $30 \%$. Following this study, Pezerat et al. (2020) showed that a dissipation coefficient $B$ taken at 40 times the local bed slope strongly improves wave predictions at gently sloping shorefaces $(\sim 1: 1000)$. At both study sites, bottom slopes are much steeper (1:50 to 1:100), so that this adaptive parametrisation results in values for $B$ close to the default value of 1 . Indeed, a sensitivity analysis shows that the adaptive parametrisation of Pezerat et al. (2020) yields very similar short wave and setup predictions compared to the default values for 
$\gamma$ and $B$ in the model of Battjes and Janssen (1978). New field experiments are required to investigate further wave dissipation mechanisms in coastal zones and validate the numerical model under very high energetic conditions, although such field deployments remain very challenging.

Finally, the comparison between $2 \mathrm{DH}$ and $3 \mathrm{D}$ simulations reveals only modest differences, with water level and surge predictions slightly improved in 3D in Arcachon and slightly deteriorated in Bayonne (Fig. 6). In the Arcachon Lagoon, improved storm surge predictions are obtained before and during the storm peak, when winds blow from SW to W and drive an Ekman transport towards the coast, a process better represented with a 3D model (Roland et al., 2012). In the case of the Adour Estuary, maximum wave setup at adjacent beaches is slightly lower in $2 \mathrm{DH}$ compared to $3 \mathrm{D}$ but extends further offshore, thereby more impacting water levels in the estuary. Guérin et al. (2018) showed that the depth-varying circulation driven by short waves in surf zones can increase the wave setup along the coast but this process is only substantial at steep beaches (i.e. mean slope of 1:30 and over). Also, these authors reported that $3 \mathrm{D}$ runs yield larger wave setup compared to $2 \mathrm{DH}$ runs very close to the shoreline, so that reproducing these differences requires a spatial resolution of a few meters, that is one order a magnitude finer than in this study.

\subsection{Momentum balance}

Previous studies already reported the development of a wave setup in inlets, river entrances and shallow lagoons (Hanslow and Nielsen, 1992; Hanslow et al., 1996; Dunn et al., 2001; Oshiyama et al., 2001; Tanaka et al., 2001, 2003; Nguyen et al., 2007; Bertin et al., 2009; Malhadas et al., 2009; Olabarrieta et al., 2011; Dodet et al., 2013; Wargula et al., 2018), which can be further investigated by analysing the momemtum balance at the inlet. Hench and Luettich Jr (2003) analysed the momentum balance without waves in the Beaufort Inlet in North Carolina and in an idealized inlet and reported that near maximum flood and ebb, the along-stream momentum balance in both cases is dominated by advection, barotropic pressure gradient and bottom friction. Olabarrieta et al. (2011) corroborated these results in a study conducted in Willapa Bay (USA) during a storm event. By activating the wave forces in their fully-coupled modelling system, they also revealed that they can substantially change the barotropic pressure gradient and the bottom friction while being one of the dominant terms in the momentum balance in the inlet area. These findings were then corroborated by Dodet et al. (2013) and Wargula et al. (2014). In particular, Dodet et al. 
(2013) combined both modelling and observations to study wave-current interactions on the Albufeira Lagoon, a shallow wave-dominated tidal inlet in Portugal, during energetic oceanic swells conditions. The authors showed that the wave forces term oriented toward the lagoon was of the same order of magnitude as the other terms in the momentum balance in the inlet, which therefore had a significant impact on the hydrodynamics, including a setup that developed within the lagoon. Recently, Fortunato et al. (2017) conducted a high-resolution hindcast of the storm surge associated with the 1941 storm that made landfall in the North of Portugal and has driven the development of a large surge in the Tagus Estuary. Their model results suggested that the breaking of storm waves generated a wave setup up to $0.50 \mathrm{~m}$ in the Tagus Estuary, showing that a substantial wave setup can also impact water levels at the scale of a large estuary. This phenomenon is explained by the authors as the result of large onshore-directed wave forces owing to storm waves breaking over the ebb delta, generating a wave setup that extended beyond the surf zone and in the inlet. The previous analysis of Fig. 4 and Fig. 5 suggests that such a phenomenon occurred at the Arcachon Lagoon during Klaus: large wave breaking on the ebb delta generated a wave setup that affected the whole lagoon.

To understand the underlying mechanisms, the magnitude of the leading terms of the momentum equations, i.e. the barotropic pressure gradient term (third term of the right hand side of Eqs. (2) - (3)), the wave forces (last term of the right hand side of Eqs. (2) - (3)), the bottom stress and surface stress terms are computed at the inlet of the Arcachon Lagoon (Fig. 7). In order to analyse the momentum balance at mid-flood and mid-ebb under similar forcing corresponding to the peak of the storm, two additional simulations are performed where tides are shifted. 

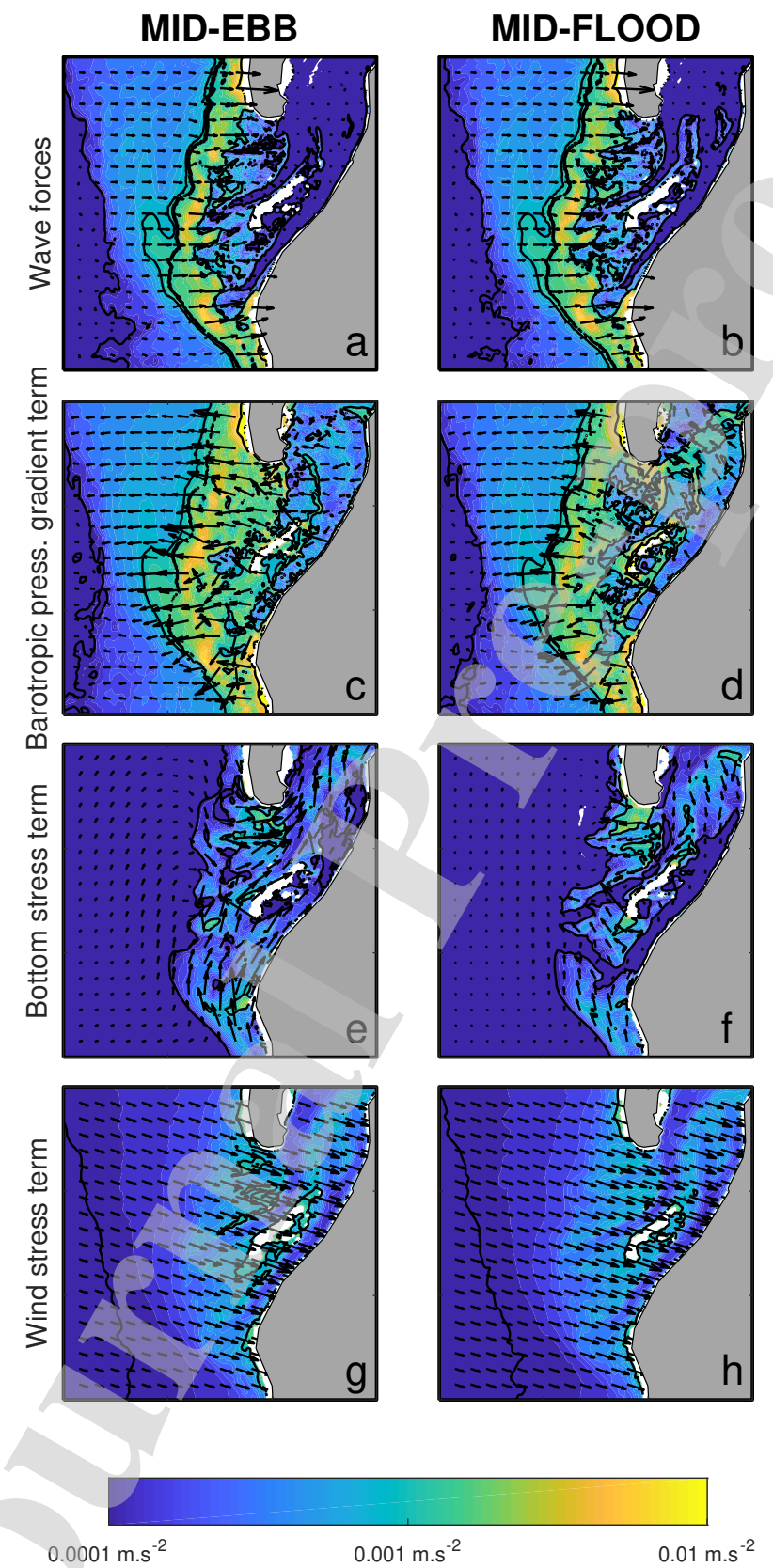

Figure 7: Leading terms of the momentum balance at mid-ebb and mid-flood: wave forces (a-b), barotropic pressure gradient term (c-d), bottom stress term (e-f) and wind stress term (g-h), at mid-ebb (left) and mid-flood (right). The magnitude and direction of each term are represented by the map colors and the vectors respectively. 
The analysis of Fig. 7 shows that the outer part of the inlet behaves like a sandy beach, with a balance between the wave forces (hereafter WF) and the barotropic pressure gradient (hereafter BPG) term (Battjes and Stive, 1985; Lentz and Raubenheimer, 1999). In this area, the WF reach values one order of magnitude larger than the bottom stress (hereafter BS) and the surface stress (hereafter SS) terms. The dominant role of WF in the momentum balance at the inlet corroborates the findings of Olabarrieta et al. (2011) and Dodet et al. (2013). In the inlet channel, the WF become much weaker and the alongstream dynamics is controlled by a balance between the BPGR and the BS terms, which is typical of tidal channels (Hench and Luettich Jr, 2003). Between the flood and the ebb, the signs of the BPGR and the BS terms are inverted, except in the outer part of the inlet where the BPGR term compensates the WF during all tidal phases.

The major contribution of the wave forces to the momentum balance in the inlet directly explains the strong effect of short-wave breaking on the hydrodynamics, the main impact being a wave setup that reaches several tens of centimetres within the lagoon (Fig. 4). In more details, the rapid decrease in WF inside the lagoon explains that wave setup displays a plateau inside the lagoon (Fig. 5-f). Over the ebb delta, the wind-driven surge reaches approximately $0.4 \mathrm{~m}$ (Fig. 5 -d and assuming $0.35 \mathrm{~m}$ of inverse barometer effect), which is comparable to the wave setup while SS are one order of magnitude lower than WF. This behaviour is explained by the fact that strong WF only extend over the $3 \mathrm{~km}$-wide ebb delta while the wind effect is integrated across the $60 \mathrm{~km}$-wide shelf. Inside the lagoon, the atmospheric surge further grows as the water depth decreases (Fig. 5-d). In the Adour Estuary, the weaker atmospheric surge (Fig. 5-c) is explained not only by weaker winds (Fig. 2) but also by the narrower continental shelf. Indeed, many studies already demonstrated that, for a given wind speed, the wind-driven surge is also controlled by the shelf width, such as in the Bay of Biscay (Bertin et al., 2012), in North Sea (Wolf and Flather, 2005) or in the Gulf of Mexico (Kennedy et al., 2012).

\subsection{Tidal modulation of the wave setup}

Some of the studies that highlighted the development of a wave setup in tidal inlets also suggested that the wave setup can be tidally-modulated (Olabarrieta et al., 2011; Dodet et al., 2013; Fortunato et al., 2017). Fortunato et al. (2017) showed that the wave setup that developed in the Tagus Estuary mouth during the 1941 storm was strongly tidally-modulated with values of $0.10-0.15 \mathrm{~m}$ at high tide while being three times larger at low tide with values of $0.30-0.35 \mathrm{~m}$. The authors attributed this phenomenon to 
more intense wave breaking on the ebb delta at low tide. When waves do not break over the ebb delta, they propagate into the inlet or to the coast in the vicinity of the estuary mouth, and thus, their contribution to the setup inside the estuary is lower. In this section, the tidal modulation of the wave setup is investigated at the Arcachon Lagoon and the Adour Estuary with additional numerical experiments.

The Arcachon lagoon exhibits large intertidal flats, which makes the tidal propagation and asymmetry very sensitive to the mean water depth. Therefore, tidal propagation is different when the wave setup raises the mean water level of the lagoon. Computing the wave setup as the difference between a simulation including tides and waves and a simulation with tides only results in difference not only including the wave setup but also the differences in tidal levels due to the higher mean water level in the coupled simulation, a process also referred to as tide surge interactions. To overcome this problem, a series of stationary runs is performed with constant water levels and wave forcing (Fig. 8-A). Two sub-grids of smaller extent covering each studied area are forced at the ocean boundary by constant water elevations ranging from $-1.5 \mathrm{~m}$ to $1.5 \mathrm{~m}$, and a JONSWAP spectrum to simulate short waves. The spectrum is characterized by a significant wave height of $14 \mathrm{~m}$ and a peak period of $15 \mathrm{~s}$, which corresponds to the peak values reached during Klaus in the region. 


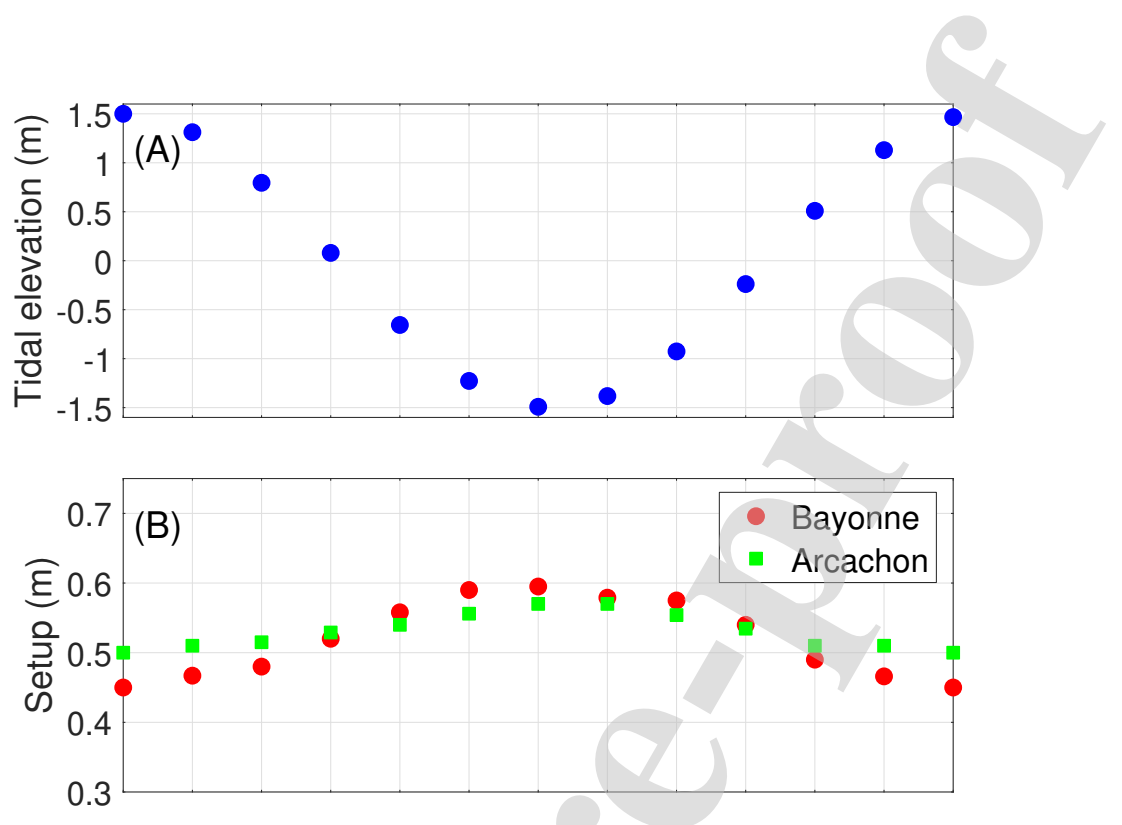

Figure 8: (A) Constant water elevations prescribed at the open boundary (blue circles). (B) Tidal modulation of the wave setup at Arcachon (green squares) and Bayonne (red circles) during a tidal cycle.

In the case of the Arcachon Lagoon, the results reveal a small tidal modulation of the order of $0.07 \mathrm{~m}$ (Fig. 8-B), the wave setup being larger at low tide. At the Adour Estuary, the tidal modulation is stronger with a wave setup reaching $0.60 \mathrm{~m}$ when the mean sea level is lowered by $1.5 \mathrm{~m}$ and decreasing to $0.45 \mathrm{~m}$ when the mean sea level is increased by $1.5 \mathrm{~m}$.

Contrary to the Tagus Estuary where the ebb delta is submerged, with depths of the order of $5 \mathrm{~m}$ relative to the mean sea level, the ebb delta of the Arcachon Lagoon extends $3 \mathrm{~km}$ offshore and includes an elongated supratidal bank, the Arguin Bank. This setting causes the wave breaking to be almost full in front of the inlet, even at high tide. At lower tidal elevations, wave energy mostly dissipates on the terminal lobe while at higher tidal stages, waves also break over the supratidal sand bank. The wave setup exhibits therefore a slight tidal modulation, unlike the Tagus Estuary (Fortunato et al., 2017). At the Adour Estuary, the bathymetry is subtidal, which implies that the lower the water level, the larger is the wave energy dissipation and the wave setup.

These results indicate that tide-induced water level variations change the spatial gradients of short-wave energy dissipation rates, which in turn controls the wave setup. Depending on the morphology of the inlet, the wave setup along the shoreline and in the lagoons or estuaries can experi- 
ence significant tidal modulations as well. Tidal currents, which are strong in estuaries or tidal inlets, can also affect the propagation of short waves (Ardhuin et al., 2012; Rusu et al., 2011; Dodet et al., 2013; Bertin et al., 2019) and subsequently the wave setup. During flood, waves following currents decrease while during ebb, waves propagating against currents increase, shifting the position of the breaking point seaward (Dodet et al., 2013). The impact of tidal currents on short-waves propagation is verified by comparing water elevations from runs including tides and waves, and activating or not the feedback of currents on waves. Model results at the Arcachon Lagoon and at the Adour Estuary show that switching off the effects of tidal currents on short-wave propagation has a small impact on wave setup (lower than $0.01 \mathrm{~m}$ ). This finding corroborates the study of Fortunato et al. (2017) which reported that the tide-induced water level variations at the mouth of the Tagus Estuary are the main driver for the tidal modulation of the wave setup compared to tidal currents effects.

The comparison of the effect of tides on wave setup between both studied locations emphasises that tidal modulation is site-specific. In areas such as the Adour Estuary, the higher wave setup is produced close to low tide, and the tidal modulation amplitude increases with increasing tidal range. Such tidal modulation can therefore limit the contribution of short-wave breaking to coastal flooding, which mostly occurs during high tide in macro tidal regions.

\subsection{Sensitivity of storm surge and wave setup calculation to spatial resolu-} tion

Recently, several storm surge numerical models using unstructured grids have been developed (e.g. Kerr et al., 2013). Such models allow to correctly represent complex shorelines and coastal embayments, using a variable grid resolution, usually coarse in the deep ocean (several kilometers to tens of kilometers) and down to few hundreds of meters in the nearshore. However, such resolution in coastal areas may not be sufficient to adequately represent small coastal morphological features, such as lagoons, and thus, enable the model to provide accurate storm surge predictions (Shen et al., 2006). Also, this study reveals that the wave setup generated by wave breaking during extreme events can greatly contribute to the storm surge, even in areas sheltered from wave breaking such as lagoons and estuaries. Accounting for short waves in storm surge operational modelling is thus of key importance to correctly predict water levels in coastal areas during storm events and thereby, improve emergency responses. However, a good evaluation of the wave setup requires a resolution fine-enough in the surf zones, which is 

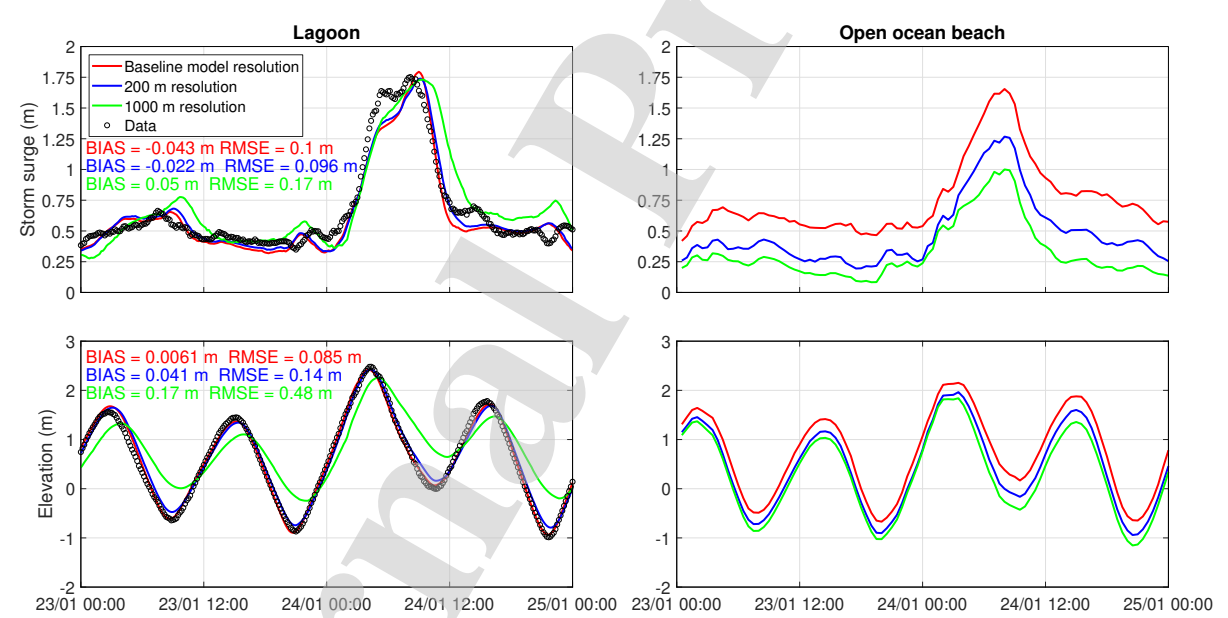

Figure 9: Simulated storm surge in the inner part of the lagoon and at the adjacent beach
to the south, with the baseline model resolution, $200 \mathrm{~m}$ resolution and $1000 \mathrm{~m}$ resolution.

Figure 9: Simulated storm surge in the inner part of the lagoon and at the adjacent beach
to the south, with the baseline model resolution, $200 \mathrm{~m}$ resolution and $1000 \mathrm{~m}$ resolution.

not always possible in operational modelling systems (Kohno et al., 2018). Therefore, an important question rises here: how well do surf zones need to be spatially resolved in order to correctly estimate the contribution of wave setup to the storm surge?

The sensitivity of the storm surge/wave setup to the model resolution is analysed at the Arcachon Lagoon region by simulating the sea state and storm surge associated to Klaus with different grid resolutions. The grid resolution used for the baseline model (hereafter BM), which goes down to $35 \mathrm{~m}$ in the nearshore, is modified to get two additional computational grids with spatial resolution from the inner shoreface to the nearshore degraded to 200 and $1000 \mathrm{~m}$. The surge is evaluated at two locations along the coastline: in the inner part of the lagoon at the Eyrac tide gauge and at the shoreline exposed to the ocean, computed as the average value of the storm surge in an area defined to the south of the inlet (see Fig. 1-B). This sensitivity analysis is not carried out at the Adour Estuary since the inlet mouth, with a maximum width of $150 \mathrm{~m}$, cannot be represented with such resolutions.

The results show that the modelled water levels and storm surge on the open ocean beach are lower when the grid resolution coarsens (Fig. 9). Indeed, while tidal predictions show little sensitivity to the grid resolution, the peak of the surge simulated with the BL resolution reaches $1.65 \mathrm{~m}$ while being $30 \%$ and $65 \%$ higher than the surges obtained with the $200 \mathrm{~m}$ and $1000 \mathrm{~m}$ resolutions respectively. A detailed analysis reveals that these 
differences are mostly explained by wave setup, which is poorly represented with a coarse grid.

In the lagoon, the results reveal a different behaviour of the model (Fig. 9 ). Surprisingly, the predicted storm surge is less sensitive to the grid resolution compared to the open ocean beach. The three grid resolutions well reproduce the peak of the surge, with the $200 \mathrm{~m}$ and $1000 \mathrm{~m}$ grid resolutions resulting in a slightly lower surge than the BM resolution $(0.05 \mathrm{~m})$. However, the storm surge modelled over the total duration of the storm is deteriorated with the $1000 \mathrm{~m}$ resolution (RMSE of $0.17 \mathrm{~m}$ ) compared to the $\mathrm{BM}$ and $200 \mathrm{~m}$ resolutions (RMSE of $\sim 0.1 \mathrm{~m}$ ). Also, water elevation is poorly predicted with the $1000 \mathrm{~m}$ resolution, which yields a RMSE of $0.48 \mathrm{~m}$, against $0.085 \mathrm{~m}$ and $0.14 \mathrm{~m}$ with the BM and $200 \mathrm{~m}$ grid resolutions respectively. As soon as the channels of the lagoon are not correctly represented, the tidal propagation in the lagoon is poorly reproduced, which impacted the predictions of water level and storm surge.

This sensitivity analysis of model results to grid resolution reveals a constrasting situation between the inner lagoon, where wave setup is reasonnably represented even with a coarse resolution and adjacent sandy beaches, where modelled wave setup is almost nil when using a coarse resolution. This behaviour is directly explained by the cross shore extension of the surf zone, which is of the order of $1000 \mathrm{~m}$ at adjacent beaches but range from 3000 to $5000 \mathrm{~m}$ in front of the lagoon. As a rough guideline, we estimate that accounting for wave setup in storm surge models requires at least 5 grid elements across the surf zone, which implies the use of a finer spatial resolution when the beach slope increases and the wave height decreases. This corroborates the findings of Nayak et al. (2012), who investigated the sensitivity of wave setup predictions to grid resolution considering idealized beaches of slope ranging from 1:80 to 1:10.

\section{Conclusion}

The fully-coupled modelling system SCHISM using a vortex force formalism was used to hindcast the sea state and storm surge associated to the strongest storm that occurred in the southern part of the Bay of Biscay for the last 20 years. After the verification of the model with wave and water level observations available during the storm, the analyses of the simulations revealed that the predictions of the storm surges at the Arcachon Lagoon and the Adour Estuary were improved by 50 to $60 \%$ when the wave forces were accounted for. The wave setup induced by the storm waves breaking in the vicinity of these two inlets extended outside the surf zones and 
significantly increased the water level at the scale of the whole lagoon and estuary.

To understand the impact of storm wave breaking on the hydrodynamics of the tidal inlets, the local momentum balance was analysed at the inlet of the Arcachon Lagoon. By reaching values one order of magnitude larger than the bottom stress and the surface stress terms, the wave forces were one of the leading terms of the momentum balance and thereby greatly affected hydrodynamics in the inlet, the main impact being the development of a wave setup at the scale of the whole lagoon.

Further analysis showed that the wave setup in tidal inlets can be tidallymodulated while this phenomenon is site-specific and depends on the morphology of the inlet. At Arcachon, as the ebb delta is characterised by supra-tidal sand banks, wave breaking is total at all tidal phases, the wave setup exhibits therefore a slight tidal modulation. At Bayonne, waves are subjected to more intense breaking at low tide than at high tide, the tidal modulation of the wave setup is thus more pronounced.

Finally, a sensitivity analysis of the storm surge and wave setup to the spatial resolution of the computational grid was carried out. This work revealed that the calculated wave setup at the shoreline is highly sensitive to the grid resolution. In the lagoon, the modelled storm surge and wave setup were found to be comparable between different grid resolutions, while tidal propagation cannot be accurately represented with a resolution of $1000 \mathrm{~m}$. This study highlighted the need to account for wave breaking in operational storm surge models, although resolving the wave setup requires a spatial resolution that depends on the width of the surf zone, itself controlled by the bottom slope and the wave height.

In a context of upcoming altimetry satellite missions with spatial footprints below $1000 \mathrm{~m}$ (SWOT, Durand et al., 2010), the results presented in this study are of key importance as they show that the wave setup can impact the water level in sheltered areas such as harbours, large lagoons and estuaries. As these coastal areas are usually instrumented with tide gauges that are used to calibrate altimeter measurement systems, it is crucial to determine the physical drivers of the water level variations recorded at these stations.

\section{Appendix A.}

The underestimation of the storm surge before the peak of the surge can be attributed to a negative bias in the $10 \mathrm{~m}$ wind speed of CFSR. In order 
to verify this hypothesis, the modelled wind speed from CFSR is increased by $12-15 \%$ over three time steps before the storm peak (Fig. A.10-A).
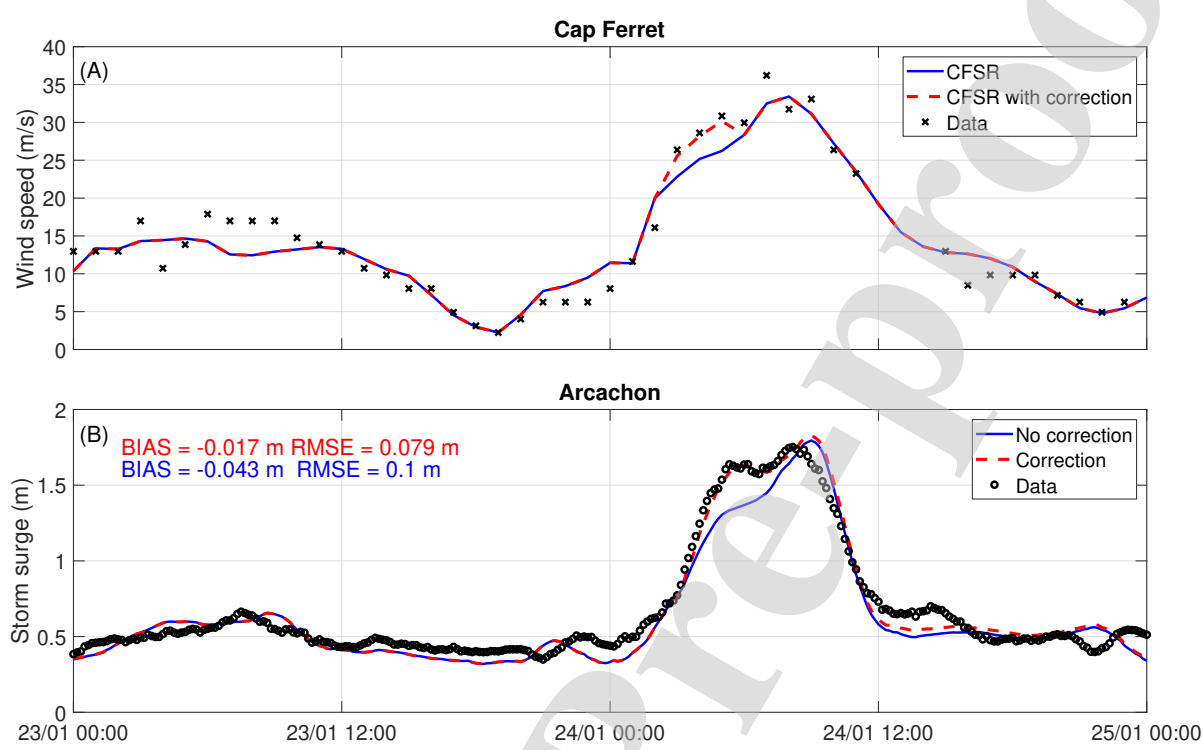

Figure A.10: (A) Measured (black crosses) against CFSR wind speed with correction (red dashed line) and original data (blue line). (B) Observed (black dots) against modelled storm surges with the corrected wind speed (red dashed line) and the original wind speed (blue line).

The comparison between the original modelled storm surge and the storm surge computed with the tuned wind speed (Fig. A.10-B) shows a significant difference at the considered period. The RMSE is improved by $20 \%$ and the localised error is cancelled out. These results confirm that the underestimation of the storm surge at this stage of the storm is due to a local negative bias in the modelled wind speed of the order of $4 \mathrm{~m} \cdot \mathrm{s}^{-1}$.

\section{Acknowledgements}

The Editor as well as the three anonymous reviewers are greatly aknowledged for their constructive comments, which resulted in a substantial improvement of this paper. LL is supported by a $\mathrm{PhD}$ fellowship from the Region Nouvelle-Aquitaine and the UNIMA engineering consulting company. Xavier Bertin thanks the support from the Regional Chaire Program EVEX, funded by Region Poitou-Charentes. Kévin Martins acknowledges the financial support from the University of Bordeaux, through an 
International Postdoctoral Grant (Idex, nb. 1024R-5030). The authors greatly acknowledge SCHISM developers' community. Wave data in the Bay of Biscay were provided by Mto-France, UK Met Office, CEREMA (http://candhis.cetmef.developpement-durable.gouv.fr) and Puerto del Estado (http://www.puertos.es). Water level data and atmospheric forcings were provided by the French Oceanographic and Hydrographic Institute (SHOM) through the REFMAR portal (http://data.shom.fr) and NCEP CFSR respectively.

\section{References}

Aon-Benfield, 2010. Annual global climate and catastrophe report: Impact forecasting - 2009 URL: http://www.aon.com.

Apotsos, A., Raubenheimer, B., Elgar, S., Guza, R., Smith, J.A., 2007. Effects of wave rollers and bottom stress on wave setup. Journal of Geophysical Research: Oceans 112.

Ardhuin, F., Rascle, N., Belibassakis, K.A., 2008. Explicit wave-averaged primitive equations using a generalized lagrangian mean. Ocean Modelling $20,35-60$.

Ardhuin, F., Rogers, E., Babanin, A.V., Filipot, J.F., Magne, R., Roland, A., Van Der Westhuysen, A., Queffeulou, P., Lefevre, J.M., Aouf, L., et al., 2010. Semiempirical dissipation source functions for ocean waves. part i: Definition, calibration, and validation. Journal of Physical Oceanography 40, 1917-1941. doi:10.1175/2010JP04324.1.

Ardhuin, F., Roland, A., Dumas, F., Bennis, A.C., Sentchev, A., Forget, P., Wolf, J., Girard, F., Osuna, P., Benoit, M., 2012. Numerical wave modeling in conditions with strong currents: Dissipation, refraction, and relative wind. Journal of Physical Oceanography 42, 2101-2120. doi:10. 1175/JPO-D-11-0220.1.

Arnaud, G., Bertin, X., 2014. Contribution du setup induit par les vagues dans la surcote associée à la tempête Klaus. XIII emes Journées Nationales Génie Côtier Génie Civil, Paralia Ed., Dunkerque, France , 2-4.

Aucan, J., Hoeke, R., Merrifield, M., 2012. Wave-driven sea level anomalies at the Midway tide gauge as an index of North Pacific storminess over the past 60 years. Geophysical Research Letters 39. doi:10.1029/ 2012GL052993. 
Battjes, J.A., Janssen, J., 1978. Energy loss and set-up due to breaking of random waves, in: Coastal Engineering 1978, pp. 569-587. doi:10.1061/ 9780872621909.034

Battjes, J.A., Stive, M.J.F., 1985. Calibration and verification of a dissipation model for random breaking waves. Journal of Geophysical Research: Oceans 90, 9159-9167. doi:10.1029/JC090iC05p09159.

Bellafont, F., Morichon, D., Roeber, V., André, G., Abadie, S., 2018. Oscillations portuaires forcées par les ondes infra-gravitaires dans un chenal de navigation, in: XVèmes Journées Nationales Génie Côtier -Génie Civil, Paralia CFL, La Rochelle, France, France. pp. 1-8. doi:10.5150/jngcgc . 2018.001.

Bennis, A.C., Ardhuin, F., Dumas, F., 2011. On the coupling of wave and three-dimensional circulation models: Choice of theoretical framework, practical implementation and adiabatic tests. Ocean Modelling 40, 260272 .

Bertin, X., Bruneau, N., Breilh, J.F., Fortunato, A.B., Karpytchev, M., 2012. Importance of wave age and resonance in storm surges: The case Xynthia, Bay of Biscay. Ocean Modelling 42, 16-30. doi:10.1016/j . ocemod.2011.11.001.

Bertin, X., Fortunato, A.B., Dodet, G., 2015b. Processes controlling the seasonal cycle of wave-dominated inlets. Revista de Gestão Costeira Integrada-Journal of Integrated Coastal Zone Management 15, 9-19.

Bertin, X., Fortunato, A.B., Oliveira, A., 2009. A modeling-based analysis of processes driving wave-dominated inlets. Continental Shelf Research 29, 819-834. doi:"10.1016/j.csr.2008.12.019".

Bertin, X., Li, K., Roland, A., Bidlot, J.R., 2015a. The contribution of shortwaves in storm surges: Two case studies in the Bay of Biscay. Continental Shelf Research 96,1-15. doi:10.1016/j.csr.2015.01.005.

Bertin, X., Mendes, D., Martins, K., Fortunato, A.B., Lavaud, L., 2019. The closure of a shallow tidal inlet promoted by infragravity waves. Geophysical Research Letters 46, 6804-6810. doi:10.1029/2019GL083527.

Brière, C., 2005. Etude de l'hydrodynamique d'une zone côtière anthropisée: l'embouchure de l'Adour et les plages adjacentes d'Anglet. Ph.D. thesis. Pau. 
Brown, J.M., Bolaños, R., Wolf, J., 2013. The depth-varying response of coastal circulation and water levels to $2 \mathrm{D}$ radiation stress when applied in a coupled wave-tide-surge modelling system during an extreme storm. Coastal Engineering 82, 102-113. doi:10.1016/j.coastaleng. 2013.08. 009.

Brown, J.M., Wolf, J., 2009. Coupled wave and surge modelling for the eastern Irish Sea and implications for model wind-stress. Continental Shelf Research 29, 1329-1342. doi:10.1016/j.csr.2009.03.004.

Butel, R., Dupuis, H., Bonneton, P., 2002. Spatial variability of wave conditions on the French Atlantic coast using in-situ data. Journal of Coastal Research 36, 96-109. doi:10.2112/1551-5036-36.sp1.96.

Cayocca, F., 1996. Modélisation morphodynamique d'une embouchure tidale: application aux passes d'entrée du Bassin d'Arcachon. Ph.D. thesis. Bordeaux 1.

Charnock, H., 1955. Wind stress on a water surface. Quarterly Journal of the Royal Meteorological Society 81, 639-640. doi:10.1002/qj . 49708135027.

Codiga, D.L., 2011. Unified tidal analysis and prediction using the UTide Matlab functions. Graduate School of Oceanography, University of Rhode Island Narragansett, RI.

Dietrich, J., Bunya, S., Westerink, J., Ebersole, B., Smith, J., Atkinson, J., Jensen, R., Resio, D., Luettich, R., Dawson, C., et al., 2010. A highresolution coupled riverine flow, tide, wind, wind wave, and storm surge model for southern Louisiana and Mississippi. Part II: Synoptic description and analysis of Hurricanes Katrina and Rita. Monthly Weather Review 138, 378-404. doi:10.1175/2009MWR2907.1.

Dodet, G., Bertin, X., Bouchette, F., Gravelle, M., Testut, L., Wöppelmann, G., 2019. Characterization of sea-level variations along the metropolitan coasts of France: waves, tides, storm surges and long-term changes. Journal of Coastal Research 88, 10-24. doi:10.2112/SI88-003.1.

Dodet, G., Bertin, X., Bruneau, N., Fortunato, A.B., Nahon, A., Roland, A., 2013. Wave-current interactions in a wave-dominated tidal inlet. Journal of Geophysical Research: Oceans 118, 1587-1605. doi:10.1002/jgrc. 20146 
Donelan, M.A., Dobson, F.W., Smith, S.D., Anderson, R.J., 1993. On the dependence of sea surface roughness on wave development. Journal of physical Oceanography 23, 2143-2149. doi:10.1175/1520-0485(1993) 023<2143: OTDOSS $>2.0$. CO $;$.

Doodson, A.T., 1924. Meteorological perturbations of sea-level and tides. Geophysical Supplements to the Monthly Notices of the Royal Astronomical Society 1, 124-147. doi:10.1111/j.1365-246X.1924.tb05363.x.

Dunn, S.L., Nielsen, P., Madsen, P.A., Evans, P., 2001. Wave setup in river entrances, in: Coastal Engineering 2000, pp. 3432-3445. doi:10.1061/ 40549 (276) 267.

Durand, M., Fu, L., Lettenmaier, D.P., Alsdorf, D.E., Rodriguez, E., Esteban-Fernandez, D., 2010. The Surface Water and Ocean Topography Mission: Observing Terrestrial Surface Water and Oceanic Submesoscale Eddies. Proceedings of the IEEE 98, 766-779. doi:10.1109/JPROC. 2010. 2043031.

Eldeberky, Y., 1996. Nonlinear transformation of wave spectra in the nearshore zone (Ph. D. thesis). Netherlands: Delft University of Technology, Department of Civil Engineering .

Flather, R.A., 2001. Storm Surges. pp. 2882-2892. doi:10.1006/rwos. 2001.0124 .

Fortunato, A.B., Freire, P., Bertin, X., Rodrigues, M., Ferreira, J., Liberato, M.L., 2017. A numerical study of the February 15, 1941 storm in the Tagus estuary. Continental Shelf Research 144, 50-64. doi:10.1016/j . csr.2017.06.023.

Guérin, T., Bertin, X., Coulombier, T., de Bakker, A., 2018. Impacts of wave-induced circulation in the surf zone on wave setup. Ocean Modelling 123, 86-97. doi:10.1016/j.ocemod.2018.01.006.

Hanslow, D.J., Nielsen, P., 1992. Wave setup on beaches and in river entrances, in: Coastal Engineering 1992, pp. 240-252. doi:10.1061/ 9780872629332.018 .

Hanslow, D.J., Nielsen, P., Hibbert, K., 1996. Wave Setup at River Entrances. pp. 2244-2257. doi:10.1061/9780784402429.174. 
Hasselmann, K., Barnett, T., Bouws, E., Carlson, H., Cartwright, D., Enke, K., Ewing, J., Gienapp, H., Hasselmann, D., Kruseman, P., et al., 1973. Measurements of wind-wave growth and swell decay during the Joint North Sea Wave Project (JONSWAP). Ergänzungsheft 8-12 .

Hasselmann, S., Hasselmann, K., Allender, J., Barnett, T., 1985. Computations and parameterizations of the nonlinear energy transfer in a gravitywave spectrum. part ii: Parameterizations of the nonlinear energy transfer for application in wave models. Journal of Physical Oceanography 15, 1378-1391. doi:10.1175/1520-0485 (1985) 015<1378: CAPOTN>2 . 0. C0; 2.

Hayes, M.O., 1980. General morphology and sediment patterns in tidal inlets. Sedimentary geology 26, 139-156.

Hench, J.L., Luettich Jr, R.A., 2003. Transient tidal circulation and momentum balances at a shallow inlet. Journal of Physical Oceanography 33, 913-932. doi:10.1175/1520-0485 (2003) 33<913: TTCAMB>2 . 0 . C0; 2.

Holman, R., Sallenger Jr, A., 1985. Setup and swash on a natural beach. Journal of Geophysical Research: Oceans 90, 945-953. doi:10.1029/ JC090iC01p00945.

Hwang, P.A., Reul, N., Meissner, T., Yueh, S.H., 2019. Whitecap and wind stress observations by microwave radiometers: Global coverage and extreme conditions. Journal of Physical Oceanography 49, 2291-2307. doi:10.1175/JPO-D-19-0061.1.

Karpytchev, M., Ballu, V., Krien, Y., Becker, M., Goodbred, S., Spada, G., Calmant, S., Shum, C.K., Khan, Z., 2018. Contributions of a Strengthened Early Holocene Monsoon and Sediment Loading to Present-Day Subsidence of the Ganges-Brahmaputra Delta. Geophysical Research Letters 45, 1433-1442. doi:10.1002/2017GL076388.

Kennedy, A.B., Westerink, J.J., Smith, J.M., Hope, M.E., Hartman, M., Taflanidis, A.A., Tanaka, S., Westerink, H., Cheung, K.F., Smith, T., et al., 2012. Tropical cyclone inundation potential on the Hawaiian Islands of Oahu and Kauai. Ocean Modelling 52, 54-68. doi:10.1016/j . ocemod. 2012.04 .009 .

Kerr, P.C., Donahue, A.S., Westerink, J.J., Luettich Jr, R., Zheng, L., Weisberg, R.H., Huang, Y., Wang, H., Teng, Y., Forrest, D., et al., 2013. US IOOS coastal and ocean modeling testbed: Inter-model evaluation of 
tides, waves, and hurricane surge in the Gulf of Mexico. Journal of Geophysical Research: Oceans 118, 5129-5172. doi:10.1002/jgrc. 20376.

Kim, S.Y., Yasuda, T., Mase, H., 2010. Wave set-up in the storm surge along open coasts during Typhoon Anita. Coastal Engineering 57, 631642. doi:10.1016/j. coastaleng. 2010.02.004.

King, B., Blackley, M., Carr, A., Hardcastle, P., 1990. Observations of wave-induced set-up on a natural beach. Journal of Geophysical Research: Oceans 95, 22289-22297. doi:10.1029/JC095iC12p22289.

Kohno, N., Dube, S.K., Entel, M., Fakhruddin, S., Greenslade, D., Leroux, M.D., Rhome, J., Thuy, N.B., 2018. Recent progress in storm surge forecasting. Tropical Cyclone Research and Review 7, 128 - 139. doi:https://doi .org/10.6057/2018TCRR02.04.

Komen, G.J., Cavaleri, L., Donelan, M., Hasselmann, K., Hasselmann, S., Janssen, P.A.E.M., 1994. Dynamics and Modelling of Ocean Waves. Cambridge University Press, Cambridge, U.K. doi:10.1017/ CB09780511628955.

Krien, Y., Karpytchev, M., Ballu, V., Becker, M., Grall, C., Goodbred, S., Calmant, S., Shum, C., Khan, Z., 2019. Present-day subsidence in the Ganges-Brahmaputra-Meghna Delta: eastern amplification of the Holocene sediment loading contribution. Geophysical Research Letters doi:10.1029/2019GL083601.

Krien, Y., Testut, L., Islam, A., Bertin, X., Durand, F., Mayet, C., Tazkia, A., Becker, M., Calmant, S., Papa, F., Ballu, V., Shum, C., Khan, Z., 2017. Towards improved storm surge models in the northern bay of bengal. Continental Shelf Research 135, 58-73. doi:https://doi.org/10.1016/ j.csr.2017.01.014.

Lentz, S., Raubenheimer, B., 1999. Field observations of wave setup. Journal of Geophysical Research: Oceans 104, 25867-25875. doi:10.1029/ 1999JC900239.

Lerma, A.N., Pedreros, R., Robinet, A., Sénéchal, N., 2017. Simulating wave setup and runup during storm conditions on a complex barred beach. Coastal Engineering 123, 29-41. doi:10.1016/j.coastaleng.2017.01. 011. 
Letetrel, C., Karpytchev, M., Bouin, M.N., Marcos, M., SantamarÍa-Gómez, A., Wöppelmann, G., 2015. Estimation of vertical land movement rates along the coasts of the Gulf of Mexico over the past decades. Continental Shelf Research 111, 42-51. doi:10.1016/j.csr.2015.10.018.

Liberato, M.L., Pinto, J.G., Trigo, I.F., Trigo, R.M., 2011. Klaus-an exceptional winter storm over northern Iberia and southern France. Weather 66, 330-334. doi:10.1002/wea. 755.

Longuet-Higgins, M.S., Stewart, R., 1962. Radiation stress and mass transport in gravity waves, with application to surf beats. Journal of Fluid Mechanics 13, 481-504. doi:10.1017/S0022112062000877.

Longuet-Higgins, M.S., Stewart, R., 1964. Radiation stresses in water waves; a physical discussion, with applications, in: Deep Sea Research and Oceanographic Abstracts, Elsevier. pp. 529-562. doi:10.1016/ 0011-7471(64) 90001-4.

Malhadas, M.S., Leitão, P.C., Silva, A., Neves, R., 2009. Effect of coastal waves on sea level in óbidos Lagoon, Portugal. Continental Shelf Research 29, 1240-1250. doi:10.1016/j.csr.2009.02.007.

Mastenbroek, C., Burgers, G., Janssen, P., 1993. The dynamical coupling of a wave model and a storm surge model through the atmospheric boundary layer. Journal of physical Oceanography 23, 1856-1866. doi:10.1175/ $1520-0485$ (1993) 023<1856: TDCOAW>2 . 0. CO $; 2$.

McWilliams, J.C., Restrepo, J.M., Lane, E.M., 2004. An asymptotic theory for the interaction of waves and currents in coastal waters. Journal of Fluid Mechanics 511, 135-178.

Melet, A., Meyssignac, B., Almar, R., Le Cozannet, G., 2018. Underestimated wave contribution to coastal sea-level rise. Nature Climate Change 8, 234. doi:10.1038/s41558-018-0088-y.

Mellor, G., 2003. The three-dimensional current and surface wave equations. Journal of Physical Oceanography 33, 1978-1989.

Michel, D., Howa, H., 1997. Morphodynamic behaviour of a tidal inlet system in a mixed-energy environment. Physics and Chemistry of the Earth 22, 339-343. doi:10.1016/S0079-1946(97)00155-9. 
Moghimi, S., Klingbeil, K., Gräwe, U., Burchard, H., 2013. A direct comparison of a depth-dependent radiation stress formulation and a vortex force formulation within a three-dimensional coastal ocean model. Ocean Modelling 70, 132-144.

Mugica, J., Delvallée, E., Pedreros, R., 2010. Application de modèles numériques pour lestimation de laltitude du plan deau à Andernos-lesBains. Technical Report. Rapport BRGM/RP-58723-FR.

Muis, S., Verlaan, M., Winsemius, H.C., Aerts, J.C., Ward, P.J., 2016. A global reanalysis of storm surges and extreme sea levels. Nature communications 7, 11969.

Nahon, A., 2018. Évolution morphologique actuelle d'une flèche littorale holocène: le Cap Ferret, à l'embouchure du Bassin d'Arcachon. Ph.D. thesis. Bordeaux.

Neumann, B., Vafeidis, A.T., Zimmermann, J., Nicholls, R.J., 2015. Future coastal population growth and exposure to sea-level rise and coastal flooding-a global assessment. PloS one 10, e0118571. doi:10.1371/ journal.pone. 0118571.

Nguyen, X.T., Tanaka, H., Nagabayashi, H., 2007. Wave Setup at River and Inlet Entrances during the Low Pressure System in 2006, in: PROCEEDINGS OF COASTAL ENGINEERING, JSCE, Japan Society of Civil Engineers. pp. 321-325.

Nicolle, A., Karpytchev, M., Benoit, M., 2009. Amplification of the storm surges in shallow waters of the Pertuis Charentais (Bay of Biscay, France). Ocean Dynamics 59, 921.

Nielsen, P., 1988. Wave setup: A field study. Journal of Geophysical Research: Oceans 93, 15643-15652. doi:10.1029/JC093iC12p15643.

Olabarrieta, M., Warner, J.C., Kumar, N., 2011. Wave-current interaction in Willapa Bay. Journal of Geophysical Research: Oceans 116. doi:10. 1029/2011JC007387.

Oshiyama, S., Lee, H., Tanaka, H., 2001. Fluctuation characteristics of water level in medium-and-small scale River mouths, in: Proceedings of 25th International Conference on Coastal Engineering, JSCE, pp. 411415 . 
Payo-Payo, M., Bertin, X., 2020. The seasonal cycle of mean sea level in the north east atlantic ocean. Journal of Coastal Research 95, 1515-1519. doi:10.2112/SI95-292.1.

Pedreros, R., Idier, D., Muller, H., Lecacheux, S., Paris, F., Yates-Michelin, M., Dumas, F., Pineau-Guillou, L., Senechal, N., 2018. Relative contribution of wave setup to the storm surge: observations and modeling based analysis in open and protected environments (Truc Vert beach and Tubuai island). Journal of Coastal Research 85, 1046-1050. doi:10.2112/SI85-210.1.

Pezerat, M., Martins, K., Bertin, X., 2020. Modelling Storm Waves in the Nearshore Area Using Spectral Models. Journal of Coastal Research 95, 1240 - 1244. doi:10.2112/SI95-240.1.

Raubenheimer, B., Guza, R., Elgar, S., 2001. Field observations of wavedriven setdown and setup. Journal of Geophysical Research: Oceans 106, 4629-4638. doi:10.1029/2000JC000572.

Roland, A., Zhang, Y.J., Wang, H.V., Meng, Y., Teng, Y.C., Maderich, V., Brovchenko, I., Dutour-Sikiric, M., Zanke, U., 2012. A fully coupled 3D wave-current interaction model on unstructured grids. Journal of Geophysical Research: Oceans 117. doi:10.1029/2012JC007952.

Rusu, L., Bernardino, M., Soares, C.G., 2011. Modelling the influence of currents on wave propagation at the entrance of the Tagus estuary. Ocean Engineering 38, 1174-1183. doi:10.1016/j.oceaneng.2011.05.016.

Saha, S., Moorthi, S., Pan, H.L., Wu, X., Wang, J., Nadiga, S., Tripp, P., Kistler, R., Woollen, J., Behringer, D., et al., 2010. The NCEP climate forecast system reanalysis. Bulletin of the American Meteorological Society $91,1015-1058$. doi:10.1175/2010BAMS3001.1.

Salles, P., Valle-Levinson, A., Sottolichio, A., Senechal, N., 2015. Winddriven modifications to the residual circulation in an ebb-tidal delta: Arcachon Lagoon, Southwestern France. Journal of Geophysical Research: Oceans 120, 728-740. doi:10.1002/2014JC010311.

Schloen, J., Stanev, E.V., Grashorn, S., 2017. Wave-current interactions in the southern North Sea: The impact on salinity. Ocean Modelling 111, 19 -37. doi:10.1016/j.ocemod.2017.01.003. 
Senechal, N., Sottolichio, A., Bertrand, F., Goeldner-Gianella, L., Garlan, T., 2013. Observations of waves' impact on currents in a mixed-energy tidal inlet: Arcachon on the southern French Atlantic coast. Journal of Coastal Research 65, 2053-2058. doi:10.2112/SI65-347.1.

Shen, J., Zhang, K., Xiao, C., Gong, W., 2006. Improved Prediction of Storm Surge Inundation with a High-Resolution Unstructured Grid Model. Journal of Coastal Research 2006, 1309 - 1319. doi:10.2112/04-0288.1.

Staneva, J., Wahle, K., Koch, W., Behrens, A., Fenoglio-Marc, L., Stanev, E.V., 2016. Coastal flooding: impact of waves on storm surge during extremes - a case study for the German Bight. Natural Hazards and Earth System Sciences 16, 2373-2389. doi:10.5194/nhess-16-2373-2016.

Stewart, R., 1974. The air-sea momentum exchange. Boundary-Layer Meteorology $6,151-167$.

Tanaka, H., Hyun-seok, L., Furumichi, K., 2003. Influence of morphological change on water level rise at the Shiribetsu River mouth. Journal of hydroscience and hydraulic engineering $21,71-78$.

Tanaka, H., Nagabayashi, H., Yamauchi, K., 2001. Observation of wave setup height in a river mouth, in: Coastal Engineering 2000, pp. 3458-3471.

Thompson, R.O.R.Y., Hamon, B.V., 1980. Wave setup of harbor water levels. Journal of Geophysical Research: Oceans 85, 1151-1152. doi:10. 1029/JC085iC02p01151.

Thornton, E.B., Guza, R.T., 1983. Transformation of wave height distribution. Journal of Geophysical Research: Oceans 88, 5925-5938. doi:10.1029/JC088iC10p05925.

Umlauf, L., Burchard, H., 2003. A generic length-scale equation for geophysical turbulence models. Journal of Marine Research 61, 235-265.

Wargula, A., Raubenheimer, B., Elgar, S., 2014. Wave-driven along-channel subtidal flows in a well-mixed ocean inlet. Journal of Geophysical Research: Oceans 119, 2987-3001. doi:10.1002/2014JC009839.

Wargula, A., Raubenheimer, B., Elgar, S., Chen, J.L., Shi, F., Traykovski, P., 2018. Tidal Flow Asymmetry Owing to Inertia and Waves on an Unstratified, Shallow Ebb Shoal. Journal of Geophysical Research: Oceans 123, 6779-6799. doi:10.1029/2017JC013625. 
Wolf, J., Flather, R.A., 2005. Modelling waves and surges during the 1953 storm. Philosophical Transactions of the Royal Society A: Mathematical, Physical and Engineering Sciences 363, 1359-1375. doi:10.1098/rsta. 2005.1572.

Ye, F., Zhang, Y.J., Yu, H., Sun, W., Moghimi, S., Myers, E., Nunez, K., Zhang, R., Wang, H.V., Roland, A., Martins, K., Bertin, X., Du, J., Liu, Z., 2020. Simulating storm surge and compound flooding events with a creek-to-ocean model: Importance of baroclinic effects. Ocean Modelling 145, 101526. doi:10.1016/j.ocemod.2019.101526.

Zhang, Y., Baptista, A.M., 2008. Selfe: A semi-implicit EulerianLagrangian finite-element model for cross-scale ocean circulation. Ocean Modelling 21, 71 - 96. doi:10.1016/j.ocemod.2007.11.005.

Zhang, Y.J., Ateljevich, E., Yu, H.C., Wu, C.H., Yu, J.C., 2015. A new vertical coordinate system for a 3D unstructured-grid model. Ocean Modelling 85, 16 - 31. doi:10.1016/j .ocemod.2014.10.003.

Zhang, Y.J., Ye, F., Stanev, E.V., Grashorn, S., 2016. Seamless cross-scale modeling with SCHISM. Ocean Modelling 102, $64-81$. doi:10.1016/j . ocemod.2016.05.002. 
- High-resolution hindcast of sea state and storm surge associated with storm Klaus.

- The wave setup substantially contributes to the storm surge in sheltered areas.

- The wave forces play a dominant role in the momentum balance at the inlet.

- The wave setup can be tidally-modulated while this process is site-specific.

- Wave setup calculation requires a high grid resolution of open-ocean coastal areas. 
Author statement

Laura Lavaud: Writing - Original Draft, Software, Investigation, Formal analysis Xavier Bertin: Supervision, Conceptualization, Methodology, Software, Investigation, Formal analysis, Writing - Original Draft Kévin Martins: Software, Investigation, Formal analysis, Writing - Original Draft Gael Arnaud: Investigation, Formal analysis Marie-Noëlle Bouin: Investigation, Formal analysis 


\section{Declaration of interests}

\The authors declare that they have no known competing financial interests or personal relationships that could have appeared to influence the work reported in this paper.

$\square$ The authors declare the following financial interests/personal relationships which may be considered as potential competing interests: 